\title{
TRADUÇÃO \\ Crise de legitimação? Sobre as contradições políticas do capitalismo financeirizado ${ }^{1}$
}

Nancy Fraser ${ }^{2}$

Resumo: Democracia de fachada. Pós-democracia. Democracia moribunda. Desdemocratização. Ao multiplicarem tais termos, muitos observadores introduzem a hipótese de que estamos passando por uma "crise da democracia". Mas o que exatamente está em crise aqui? Defendo que as atuais aperturas da democracia são melhor compreendidas como expressões, sob condições contemporâneas historicamente específicas, de uma tendência geral à crise política que é intrínseca às sociedades capitalistas. Desenvolvo essa tese em três passos. Primeiro, proponho uma explicação geral da "contradição política do capitalismo" enquanto tal, sem referência a qualquer forma histórica particular. Em seguida, reconstruo Problemas de Legitimação no Capitalismo Tardio, livro de Jürgen Habermas publicado em 1973, como uma explicação da forma que essa contradição política assumiu numa fase específica da sociedade capitalista, a saber, o capitalismo estatalmente administrado do período subsequente à Segunda Guerra Mundial. Por último, esboço uma explicação dos problemas atuais da democracia como expressões da contradição política do capitalismo em sua presente fase, a financeirizada.

Democracia de fachada. Pós-democracia. Democracia moribunda. Desdemocratização. Tais expressões estão proliferando atualmente, ganhando o espaço anteriormente ocupado pelo tema da democracia “deliberativa”. Isso sugere claramente que os problemas crônicos da democracia passaram do quadro de melhora para o estágio de crise. E quem poderia discordar? A comprovação inclui declínios no comparecimento eleitoral, a proliferação da corrupção e do dinheiro graúdo na política, um aumento da concentração da propriedade de mídia, uma elevação do extremismo de direita, o virtual colapso dos partidos tradicionais de esquerda no

\footnotetext{
1 Por comentários proveitosos, sou grata a Robin Blackburn, Hauke Brunkhorst, Claudio Corradetti, Robert Gooding-Williams, Bernard Harcourt, Jennifer Nedelsky, Max Pensky, William E. Scheuerman, Melissa Williams, Eli Zaretsky, Linda Zerilli e um avaliador anônimo de Critical Historical Studies.

[Texto original: Fraser, N. (2015). Legitimation crisis? On the political contradictions of financialized capitalism. Critical Historical Studies, 2(2), pp.157-189. DOI: https://doi.org/10.1086/683054. Tradução de José Ivan Rodrigues de Sousa Filho (Universidade Federal de Santa Catarina, CAPES), com a expressa autorização da autora (titular dos direitos autorais) e com o benefício da cuidadosa revisão de um par anônimo de pareceristas. (N. T.)]
}

2 Nancy Fraser é professora da New School for Social Research. 
Norte Global, o agudo estreitamento do espectro das diferenças entre as diretrizes políticas na medida em que quase todos os partidos se apressam para apaziguar os mercados de títulos, a insatisfação generalizada com a União Europeia, o declínio da credibilidade dos Estados Unidos como protagonista de uma hegemonia mundial racional e legítima, a proliferação da violência política - nas mãos de Estados e forças policiais, de extremistas majoritários e minoritários, de redes organizadas e indivíduos insatisfeitos. Não são esses fenômenos sinais inequívocos do penetrante esvaziamento das formas democráticas?

Se os fenômenos são palpáveis e incontroversos, sua interpretação e sua explicação são muito menos evidentes. O que exatamente está em crise aqui, e quais são as bases e o locus do distúrbio? Os problemas atuais da democracia estão enraizados primariamente na ordem política? Podem eles ser resolvidos por meio da reforma dessa ordem - por meio, por exemplo, do fortalecimento do "ethos democrático", da reativação do "poder constituinte", da liberação da força do "agonismo", da promoção de "iterações democráticas"? Ou estamos enfrentando uma crise mais ampla, mais abrangente, da qual a "crise da democracia" não constitui senão uma vertente, vertente inextricavelmente entrelaçada com outras? E, nesse caso, que é o verdadeiro objeto da crise, e quais são suas profundas causas estruturais?

Os observadores mais perspicazes intuem que a atual crise da democracia está profundamente ligada ao advento do capitalismo neoliberal. Alguns deles, tais como Colin Crouch (2011), propõem que a raiz de nossa atual condição "pósdemocrática" é a captura do poder público por empresas oligopolistas de alcance global. Outros, tais como Wolfgang Streeck (2014), sustentam que a excepcional convergência entre democracia e capitalismo da qual o Norte Global gozou no pós-guerra tem sido desfeita por uma coordenada revolta tributária do capital empresarial, bem como pela substituição das comunidades democráticas de cidadãos pelos mercados financeiros globais como a instância soberana à qual os governos devem atender a qualquer custo. Ainda outros, tais como Wendy Brown (2006; 2015), associam a "desdemocratização" à colonização do poder público por racionalidades políticas neoliberais, as quais valorizam a eficiência e a escolha, bem como por modos neoliberais de subjetivação, os quais impõem a "autorresponsabilização" e a maximização do "capital humano" individual. Outros ainda, tais como Stephen Gill (1998), enfatizam o bloqueio da ação democrática por um "novo constitucionalismo" que estabelece a política macroeconômica neoliberal transnacionalmente, por meio de tratados que, tais como o NAFTA, consagram as constrições do livre-comércio como trunfos políticos e excluem a possibilidade de uma robusta legislação social e ambiental em prol do interesse público. ${ }^{3}$

Essas explicações nos levam para perto do cerne da questão. Buscando

3 Para uma formulação mais recente, ver Gill (2015). 
apreender uma mudança epocal, elas associam a crise democrática a uma mutação na natureza do capitalismo. É a transição do capitalismo estatalmente organizado do período do pós-guerra para o capitalismo globalizador do presente - sustentam aqueles observadores - que tem desestabilizado ordens políticas em todo o mundo, esvaziando os poderes públicos e reduzindo as instituições democráticas a cascas vazias, meras sombras do que elas mesmas já foram.

Concordo com esse diagnóstico dentro de seus limites. Mas acredito que podemos e devemos desenvolvê-lo mais - mediante a interpretação dos atuais problemas da democracia como expressões mais ou menos agudas do que chamarei de contradições políticas do capitalismo financeirizado. Essa formulação sugere três ideias. Em primeiro lugar, o advento da “pós-democracia” não é mera ocorrência acidental, mas uma ocorrência com profundas raízes sistêmicas na estrutura de nossa ordem social. Em segundo lugar, o que esse desenvolvimento sinaliza não é simplesmente uma crise política, mas algo mais amplo, uma crise geral desta ordem social que chamo de capitalismo financeirizado. Não obstante - e esse é o terceiro ponto -, os atuais processos de desdemocratização indicam que há algo podre não só na atual forma de capitalismo, a forma financeirizada, mas na sociedade capitalista per se.

Essas são as teses que desenvolverei aqui. O que argumento, para começar com o último ponto, é que toda formação social capitalista incuba uma "tendência de crise”, ou "contradição", política profundamente arraigada. De um lado, um poder público eficaz e legítimo é uma condição de possibilidade da acumulação continuada de capital; de outro lado, o impulso do capitalismo para a acumulação sem fim tende a desestabilizar o próprio poder público do qual ele depende. Sustento que essa contradição política do capitalismo está na raiz da atual crise política e do esvaziamento do poder público que muitos notaram. Inobstante inerente ao capitalismo enquanto tal, ela assume um aspecto diferente e distintivo em cada forma historicamente específica da sociedade capitalista - por exemplo, no capitalismo concorrencial liberal do séc. XIX, no capitalismo monopolista estatalmente administrado do período do pós-guerra e no capitalismo neoliberal financeirizado do tempo presente. A crise democrática que experienciamos hoje é a forma que essa contradição assume na terceira e mais recente fase do desenvolvimento capitalista.

Aseguir, desenvolverei essa hipótese em três passos. Em primeiro lugar, proporei uma explicação da contradição política do capitalismo enquanto tal, sem referência a qualquer forma histórica específica. Em segundo lugar, reconstruirei Problemas de Legitimação no Capitalismo Tardio, livro de Jürgen Habermas publicado em 1973, como uma explicação do desdobramento dessa contradição política numa das fases históricas do desenvolvimento capitalista, a saber, o capitalismo monopolista estatalmente administrado do período posterior à Segunda Guerra Mundial. Por 
último, utilizarei algumas categorias desenvolvidas por Habermas naquele livro para analisar os problemas contemporâneos da democracia como expressões da contradição política do capitalismo em sua fase atual, a fase financeirizada.

\section{A contradição política do capitalismo enquanto tal}

Os modos de compreender a crise capitalista que são padrão na esquerda enfocam as contradições internas à economia. Uma versão influente propõe que é inerente à taxa de lucro uma tendência ao declínio, tendência que pode expressarse em crises de superacumulação, superprodução e subconsumo. Não precisamos preocupar-nos aqui com os detalhes dessas explicações. O que é importante é a ideia central de que o processo de acumulação capitalista institucionaliza imperativos econômicos que, sendo mutuamente incompatíveis, tornam a dinâmica desse mesmo processo instável de modo inerente e, não obstante, tendencial, instável por razões não acidentais. No coração do capitalismo, compreendido aqui como um sistema econômico, reside, ínsita, uma tendência à autodesestabilização que se expressa periodicamente em crises econômicas.

Esse modo de compreensão pode muito bem ser correto dentro de seus limites. Mas ele não consegue retratar completamente as contradições, ou tendências de crise, inerentes ao capitalismo. Focado exclusivamente em manifestações econômicas de crise e em contradições internas à economia capitalista, o modo de compreensão que é padrão não dá conta de expressões e bases de crise outras, não econômicas. Adotando uma perspectiva economicista, ele compreende o capitalismo de maneira demasiado restrita, como um sistema econômico simpliciter. Da perspectiva da teoria crítica, o capitalismo é melhor compreendido de maneira mais ampla, como uma ordem social institucionalizada, ao par do feudalismo, por exemplo. Seu "subsistema econômico", para usar o termo de Habermas, é um importantíssimo elemento constitutivo dessa ordem social. Mas ele não é independente e não pode ser adequadamente compreendido caso seja abstraído de outros elementos constitutivos que são suas condições de possibilidade de fundo. Apenas uma compreensão alargada do capitalismo que abarque tanto sua economia oficial como as condições "não econômicas" de fundo dessa economia pode permitir-nos conceituar e criticar toda a variedade de tendências de crise do capitalismo, incluindo aquelas implicadas nos atuais processos de desdemocratização.

Para entender o porquê, consideremos que o subsistema econômico do capitalismo depende de ao menos três condições essenciais que são externas a ele. Uma dessas condições, a reprodução social, diz respeito à ampla variedade de atividades que, sendo frequentemente não remuneradas e desempenhadas por mulheres, criam e mantêm vínculos sociais e, ao mesmo tempo, também formam os 
sujeitos humanos do capitalismo, os quais são (entre outras coisas) os portadores da força de trabalho. Uma segunda condição, a ecológica, tem a ver com a natureza, a qual fornece à produção de mercadorias os indispensáveis insumos materiais e energéticos, o necessário esgoto para absorver o lixo de tal produção e a base de sustentação da vida humana e não humana. Tanto a reprodução social como a ecologia natural são indispensáveis condições de fundo de uma economia capitalista, economia que é inconcebível na ausência dessas duas condições. Ambas são importantes partes constitutivas de uma ordem social capitalista, mesmo que até agora tenham sido consideradas como não econômicas e situadas fora da economia monetizada em grande medida.

Isso também é verdadeiro quanto a um terceiro aspecto que é central para meu argumento aqui e que concerne às condições políticas de possibilidade de uma economia capitalista. 0 que está em questão aqui é a dependência que o capital tem dos poderes públicos para estabelecer e fazer cumprir suas normas constitutivas. Afinal, a acumulação de capital é inconcebível na ausência de uma estrutura jurídica que sustente a empresa privada e a troca no mercado. Ela depende, de modo crucial, dos poderes públicos para garantir direitos de propriedade, fazer cumprir contratos e julgar disputas; para suprimir rebeliões, manter a ordem e administrar o dissenso; e para manter, na linguagem da constituição estadunidense, "a fé e o crédito plenos" do dinheiro circulante, o qual constitui o sangue vital do capital.

Historicamente, os referidos poderes públicos foram alojados principalmente em Estados territoriais, incluindo aqueles que operaram como metrópoles coloniais. Foram os sistemas jurídicos de tais Estados que estabeleceram os contornos de arenas aparentemente despolitizadas no interior das quais os atores privados poderiam perseguir seus interesses "econômicos", livres de interferências "políticas", de um lado, e de obrigações de patronagem derivadas do parentesco, de outro. Além disso, foram os Estados territoriais que mobilizaram a força "legítima" para derrubar a resistência às expropriações por meio das quais as relações de propriedade capitalistas foram originadas e mantidas. Por último, foram tais Estados que nacionalizaram e afiançaram o dinheiro. Por tais vias, eles constituíram a economia capitalista.

Subsequentemente, é claro, os Estados se encarregaram de funções adicionais para sustentar a economia capitalista, incluindo o provimento e a manutenção de infraestrutura, a compensação das falhas de mercado, a direção proativa do desenvolvimento econômico, o apoio à reprodução social, a mitigação de crises econômicas e a administração dos efeitos colaterais políticos associados. Também tais esforços foram destinados a assegurar as condições da acumulação privada de capital, mesmo quando envolveram a criação de um setor público. No período moderno, além disso, a saúde do capital requer, amiúde, não apenas o poder estatal per se, mas o poder estatal legítimo, aparentemente democrático. Como veremos, 
arranjos eleitorais inclusivos podem servir como uma força estabilizadora em tempos de normalidade, assegurando a lealdade das massas ao sistema, alertando as elites da necessidade de reforma e propelindo esforços para disciplinar o capital para o próprio bem dele. Ademais, uma ampla mobilização democrática pode fornecer a musculatura política indispensável em tempos de crise, quando o capitalismo deve reorganizar-se ou morrer. Em todos os períodos, portanto, o poder estatal eficaz e legítimo é necessário para sustentar a acumulação em longo prazo.

Mas isso não é tudo. Uma economia capitalista também tem condições políticas de possibilidade no nível geopolítico. 0 que está em questão aqui é a organização do espaço mais amplo no qual os Estados territoriais estão embutidos. Trata-se de um espaço no qual o capital aparentemente se moveria com bastante facilidade, tendose em conta seu impulso expansionista. Mas sua capacidade de atravessar fronteiras depende do direito internacional, dos arranjos negociados entre as Grandes Potências e de regimes supranacionais que pacificam, em parte (e de um modo favorável ao capital), um âmbito que, por vezes, é imaginado como um estado de natureza. Ao longo de toda a história do capitalismo, sua economia depende das capacidades militares e organizacionais de uma sucessão de Estados globalmente hegemônicos, os quais, como Giovanni Arrighi (1994) defendeu, buscam promover a acumulação numa escala cada vez maior dentro da estrutura de um sistema político multiestatal.

Tanto no nível estatal-territorial como no geopolítico, portanto, a economia capitalista depende de poderes políticos externos a ela. É para apreender essa dupla dependência que emprego a expressão mais ampla "poder público", em lugar da expressão mais usual "poder estatal”. Em ambos os níveis, o poder público é uma indispensável condição sine qua non para a exploração do trabalho, para a produção e a troca de mercadorias e para a acumulação de mais-valor. Ausentes tais arranjos políticos, esses processos econômicos, capitalistas por excelência, não poderiam ser mantidos. Assim, também os poderes políticos são importantes partes constitutivas de uma ordem social capitalista. Da mesma maneira que a reprodução social e a ecologia natural, a organização do poder público é um componente necessário de uma concepção alargada do capitalismo como uma ordem social institucionalizada. Somente com um alargamento de nossa concepção do capitalismo para incluir a ordem política, podemos clarificar toda a variedade das contradições e tendências de crise do capitalismo, incluindo aquelas expressas nos atuais processos de desdemocratização.

Compreendido desse modo, como uma ordem social institucionalizada, o capitalismo se distingue de outras amplas formações sociais por sua topografia institucional específica. 0 que caracteriza o capitalismo é um distintivo conjunto de separações institucionalizadas: a separação institucionalizada da produção econômica em relação à reprodução social, a da sociedade humana em relação à 
natureza não humana e - a que é a mais relevante para nossas preocupações aqui - a do econômico em relação ao político. Essa última divisão inclui a diferenciação da economia em relação à política, do poder privado em relação ao poder público, da coerção econômica em relação à coerção política. Ela distingue as sociedades capitalistas de formas anteriores, nas quais a economia e a política se encontravam efetivamente fusionadas - distingue-as, por exemplo, da sociedade feudal, na qual o controle sobre o trabalho, a terra e a força militar estava investido na instituição única de suserania e vassalagem. Na sociedade capitalista, ao contrário, como Ellen Meiksins Wood mostrou, o poder político e o poder econômico se encontram separados; a cada um, são assinalados sua própria esfera, sua própria mediação e seu próprio modus operandi (Wood, 1981, pp.66-95). O poder de organizar a produção é privatizado e delegado ao capital, o qual, supostamente, emprega tão somente as sanções "naturais" e "não políticas” da fome e da necessidade; a tarefa de governar as demais ordens "não econômicas", incluindo as condições externas da acumulação, recai sobre o poder público, o qual pode, unicamente ele o pode, utilizar os meios "políticos" do direito e da violência "legítima". No capitalismo, portanto, o econômico é não político, o político é não econômico.

Uma versão da separação economia/política no capitalismo também aparece no nível geopolítico, cuja diferenciação em relação ao nível do Estado também é característica da ordem capitalista. Historicamente, o advento do capitalismo coincidiu com a construção da divisão westfaliana oficial entre "o doméstico" e "o internacional", tendo ele, mais tarde, dado origem também a uma divisão imperialista não oficial entre centro e periferia. O que, porém, subjaz a essas duas construções do espaço político e organiza a tensa relação entre elas é a divisão mais fundamental entre uma economia capitalista crescentemente global, organizada como um "sistema mundial", e um mundo político organizado como um sistema internacional de Estados territoriais (cf. Wallerstein, 1974).

A separação capitalista da economia em relação à política anda de mãos dadas com a dependência da economia capitalista em relação a formas extraeconômicas de poder político. Aos olhos de muitos pensadores, essa relação tanto de separação como de dependência representa um ponto forte da ordem capitalista, a base do dinamismo e da adaptabilidade que lhe são peculiares. 0 que tais pensadores negligenciam, porém, é que esse arranjo também é uma fonte ínsita de instabilidade. De um lado, a produção econômica capitalista não é autossustentável, senão que depende do poder político. De outro lado, o impulso para a acumulação ilimitada ameaça comprometer os mesmos poderes públicos, nacionais e transnacionais, dos quais o capital necessita. Como veremos, o efeito ao longo do tempo pode ser a desestabilização das necessárias condições políticas da economia capitalista.

Aqui, com efeito, encontra-se uma contradição política inerente à estrutura 
profunda da sociedade capitalista. Assim como a(s) contradição(ões) econômica(s) salientadas pelos marxistas, também essa contradição política baseia uma tendência de crise. Nesse caso, porém, a contradição não está localizada dentro da economia capitalista, mas na fronteira que separa a economia da política e, ao mesmo tempo, conecta aquela a esta. Nem intraeconômica nem intrapolítica, a contradição é entre aquelas duas importantes partes constitutivas da ordem social capitalista - ou, melhor, entre suas respectivas dinâmicas e bases normativas. ${ }^{4}$ Enquanto a dinâmica da economia se centra na acumulação ilimitada e na apropriação privada de maisvalor, a impulsão da política é desenvolver capacidades de ação pública e reservas de apoio público para legitimar o uso de tais capacidades. Assim, enquanto a economia valoriza o crescimento, a eficiência, a escolha e a liberdade negativa, a política apela ao interesse público, à igual cidadania, à legitimidade democrática e à soberania popular. Essas orientações podem entrar em conflito. Se um conflito entre elas irromperá abertamente ou não e, em irrompendo, que forma tomará, isso depende de como a separação entre a economia e a política está institucionalizada e de onde as fronteiras entre elas estão traçadas - questões que consideraremos posteriormente. Mas já deveria estar claro ao menos o seguinte: esforços para "liberar” a economia da política tendem, em longo prazo, a ser contraproducentes - é mais provável que desencadeiem a tendência de crise política inerente ao capitalismo do que a contornem.

Frequentemente, é claro, a contradição política do capitalismo é silenciosa, e a respectiva tendência de crise permanece latente. Em períodos "normais", essa latência é conservada por reformas fragmentárias que remendam e conciliam os focos de luta mais problemáticos. Mas tais consertos tendem a deteriorar-se em face de manobras engendradas por interesses empresariais, interesses que se mantêm, em geral, um passo à frente daqueles que intentam regulá-los. ${ }^{5} \mathrm{Em}$ períodos de crise, quando as instabilidades se acumulam e a colcha de retalhos regulatória se torna muito esgarçada, elites esclarecidas podem tentar instituir reformas estruturais destinadas a disciplinar o capital de um modo que torne a estabilizar suas condições de possibilidade. Mas também esses consertos podem dar errado. De modo típico, eles requerem a mobilização das classes populares contra aqueles capitalistas menos

\footnotetext{
4 Podemos também conceituar duas contradições análogas, a saber, a contradição entre economia e sociedade, de um lado, e a contradição entre economia e natureza, de outro, ambas sendo próprias do capitalismo. Elas correspondem, respectivamente, a uma tendência de crise sociorreprodutiva e a uma tendência de crise ecológica. Embora igualmente importantes e endêmicas na sociedade capitalista, não as discutirei aqui. Para uma explicação que inclui tais contradições do capitalismo, bem como a que é discutida aqui, ver Fraser (2014a).

5 Um exemplo é o desfazimento da legislação de reforma do financiamento de campanhas nos Estados Unidos, considerando que interesses de empresas e partidos exploraram brechas legais criando novos tipos de entidades jurídicas destinadas a embalar contribuições. Essas manobras já haviam eviscerado sobejamente a lei quando a Suprema Corte the deu um tiro de misericórdia no caso "Cidadãos Unidos".
} 
previdentes que estão obcecados por ganhos em curto prazo; e tais mobilizações nem sempre podem ser controladas. Por último, as reformas podem demonstrar-se, em ambos os casos, insuficientes ou contraproducentes, incapazes de neutralizar a tendência à crise política que é inerente ao capitalismo.

Essa tendência, em todo caso, torna-se aguda quando o impulso do capital para a acumulação sem limites se desprende do controle político e se volta contra suas próprias condições de possibilidade. Nesse caso, a economia invade a política, destruindo gradualmente o poder público e desestabilizando as próprias agências políticas das quais o capital depende. 0 que, então, é comprometido são as capacidades públicas nacionais e transnacionais que são necessárias para sustentar a acumulação em longo prazo. Destruindo suas próprias condições políticas de possibilidade, a dinâmica de acumulação do capital efetivamente come seu próprio rabo.

Potencialmente, as ramificações dessa contradição política do capitalismo são (pelo menos) duas. Um dos resultados pode ser uma crise administrativa, crise na qual falta aos poderes públicos o peso necessário para governar efetivamente. Em face do poder de fogo superior dos poderes privados, tais como as enormes empresas transnacionais, os poderes públicos são impedidos de criar e implementar as políticas necessárias à resolução de problemas sociais, incluindo problemas que, caso negligenciados, podem colocar em perigo as chances de sucesso duradouro da acumulação de capital. Privadas das capacidades necessárias para governar, as instituiçõos políticas são incapazes de gerar os resultados dos quais o capital assim como o resto de nós - necessita. É possível argumentar que, no tocante ao aquecimento global e às finanças globais, é precisamente isso o que está ocorrendo hoje.

Um segundo resultado pode ser uma crise de legitimação, crise na qual a opinião pública se volta contra um sistema disfuncional que não realiza o que promete. Nesse caso, as forças populares se mobilizam para opor-se à captura e ao esvaziamento dos poderes públicos. Subtraindo legitimação aos arranjos existentes, esses atores buscam (re)constituir agências políticas que possam servir ao interesse público. Protestando contra a subordinação da política à economia, bem como contra suas consequências deletérias para a ecologia e a reprodução social, eles visam reconfigurar as relações entre essas importantes partes constitutivas da sociedade capitalista. Tais "lutas fronteiriças" - é assim que as tenho chamado - buscam resolver a crise transformando a topografia institucional da ordem capitalista. ${ }^{6}$ É possível argumentar que uma crise de legitimação desse tipo deveria estar fermentando hoje.

Com efeito, crise administrativa e crise de legitimação são duas potenciais expressões da contradição política inerente à sociedade capitalista. A crise administrativa está ligada à ordem capitalista considerada como um sistema

6 Sobre o conceito de lutas fronteiriças, ver Fraser (2014a). 
autodesestabilizador. A crise de legitimação, de modo diverso, está ligada às compreensões vividas dos atores sociais que experienciam as consequências daquele sistema e que agem - ou não agem - para mudá-lo. Teoricamente, essas duas faces da crise política deveriam permanecer juntas. Uma crise administrativa deveria conduzir a uma crise de legitimação. Arranjos que impedem os poderes públicos de agir no interesse público deveriam ser expostos como ilegítimos na esfera pública. Na efervescência que daí resultaria, um inflamado agrupamento de opinião pública deveria clamar pela transformação estrutural da sociedade capitalista.

A relação entre crise administrativa e crise de legitimação figurará de modo importante nas páginas seguintes - assim como a teoria de Jürgen Habermas da qual essas categorias são extraídas. Por enquanto, porém, quero concluir este primeiro passo de minha argumentação reafirmando o ponto fundamental. A sociedade capitalista incuba uma contradição política endêmica e, portanto, uma tendência à crise política, tendência que lhe é inerente. Não sendo um mero aspecto superficial ou acidental, essa tendência está profundamente enraizada na estrutura do capitalismo - sobretudo, em sua topografia distintiva, a qual torna a economia dependente da política, mas também as separa uma da outra. Carregada de consequências potencialmente explosivas, essa contradição política profundamente arraigada está embutida, de modo originário e permanente, no capitalismo enquanto tal. ${ }^{7}$

\section{Contradições políticas do capitalismo estatalmente administrado}

Até aqui, estive elaborando a estrutura dessa tendência de crise política no que diz respeito ao capitalismo enquanto tal. Porém, a sociedade capitalista não existe enquanto tal, mas só em formas, ou regimes, historicamente específicos de acumulação. O próximo passo, portanto, é historicizar minha explicação da contradição

\footnotetext{
7 Nesta seção, na verdade, reconstruí os traços distintivos de certa crítica da sociedade capitalista, uma crítica centrada na crise - e o fiz de uma maneira que evita pelo menos três defeitos comuns de tais críticas. Enquanto a crítica centrada na crise frequentemente se torna refém do economicismo, o quadro teórico elaborado aqui supera essa falha - em primeiro lugar, expandindo o conjunto das tendências de crise de modo a abranger o político, o social e o ecológico; e, em segundo lugar, evitando pensar em termos de base/superestrutura, conforme explicado na nota 13 abaixo. Além disso, enquanto a crítica centrada na crise é tipicamente prejudicada pelo funcionalismo, minha versão evita a assunção de que as disfunções sistêmicas ditam as respostas dos atores sociais - em primeiro lugar, colocando em primeiro plano o problema do agir e, em segundo lugar, problematizando as mediações entre "sistema" e "mundo da vida". Por último, enquanto a crítica centrada na crise é comumente viciada por um pensamento teleológico, minha variante apresenta, de modo explícito, um final aberto, não decidindo entre múltiplos futuros possíveis, incluindo o advento de uma fase nova, pós-financeira, do capitalismo; um processo de lenta dissolução que culminaria num estado estacionário ou numa constante desintegração social; um interregno administrado por uma revolução passiva (se não por um fascismo explícito); e uma sociedade pós-capitalista de algum tipo (melhor ou pior). O caráter não economicista de minha abordagem já deveria estar claro. Sua orientação não funcionalista e não teleológica tornar-se-á cada vez mais evidente nas seções seguintes.
} 
política do capitalismo em relação às fases específicas de seu desenvolvimento.

Permitam-me começar observando que compreender o capitalismo como uma ordem social institucionalizada é colocar em primeiro plano seu caráter histórico. Suas divisões constitutivas, ao invés de dadas de uma vez por todas, são passíveis de contestação e de mudança. Especialmente em períodos de crise, os atores sociais travam lutas a respeito das fronteiras que delimitam a "economia", a "política", a "sociedade" e a "natureza" - e, às vezes, conseguem redefini-las. No séc. XX, por exemplo, essas demarcações se alteraram substancialmente, dado que o acirramento do conflito de classes forçou os Estados a assumir novas responsabilidades pela promoção do crescimento econômico, pelo provimento de bem-estar social e pela asseguração do abastecimento de energia. Mudanças análogas marcaram a transição para o capitalismo do séc. XXI, dado que partidários do chamado livre mercado imprimiram às regras internacionais do jogo alterações que incentivaram fortemente os Estados a apaziguar os mercados financeiros, a (re)privatizar a reprodução social e a instituir formas de ambientalismo baseadas no mercado. Em ambos os casos, o resultado foi a revisão das fronteiras previamente estabelecidas entre a produção e a reprodução, entre a sociedade humana e o ambiente natural e - o mais importante para a presente investigação - entre a economia e a política. Essa última divisão modificou-se diversas vezes no curso da história do capitalismo, assim como os poderes públicos que tornaram a acumulação possível em cada estágio.

Tais mudanças nas fronteiras marcam transformações epocais da sociedade capitalista. Se adotarmos uma perspectiva que as coloque em primeiro plano, poderemos distinguir três regimes de acumulação na história do capitalismo: o capitalismo liberal ou concorrencial do séc. XIX, regime no qual os poderes públicos dos Estados territoriais foram usados para constituir a economia capitalista; o capitalismo monopolista estatalmente administrado do séc. XX, regime no qual o poder público do nível estatal foi empregado, além do mais, em esforços para prevenir ou mitigar a crise econômica por meio do disciplinamento do capital para o próprio bem do capital; e o atual capitalismo financeirizado globalizador, regime no qual o poder estatal é cada vez mais usado para construir estruturas de governança transnacional que revestem o capital de poder. Ao longo de toda essa sequência, o aspecto repressivo do poder estatal serviu como uma indispensável precondição para a acumulação e se expandiu enormemente em tempos de crise. Mas, em cada regime, as condições políticas da economia capitalista assumiram uma forma institucional diferente tanto no nível estatal-territorial como no geopolítico. Em cada caso, ademais, a contradição política da sociedade capitalista assumiu um aspecto diferente e encontrou expressão num conjunto diferente de fenômenos de crise. ${ }^{8}$ Por último, em cada regime, a contradição política do capitalismo incitou

8 Isso também é verdadeiro no tocante às condições ecológica e sociorreprodutiva, embora elas não 
diferentes formas de luta social. ${ }^{9}$

Consideremos, primeiro, o capitalismo concorrencial liberal do séc. XIX. Nesse regime, os Estados territoriais ainda estavam preocupados, sobretudo, em constituir suas economias sobre uma base capitalista. No nível doméstico, eles empregavam a força das armas e do direito em prol das contínuas expropriações que ampliavam as fileiras tanto dos capitalistas proprietários como dos trabalhadores sem propriedade, ao passo que as lutas a respeito do sufrágio, da escravidão e das condições do trabalho fabril se inflamavam. Externamente, os Estados europeus perseguiam projetos coloniais; buscando vantagens geopolíticas vis-à-vis Estados rivais e, concomitantemente, auxiliando "seus" capitalistas na competição renhida por mercados e matérias-primas, eles impunham a subjugação imperial no exterior, ao passo que a democratização avançava internamente. Internacionalmente, todo o ordenamento passou a apoiar-se no padrão-ouro, no equilíbrio de poder e na hegemonia britânica, bases que, juntas, asseguravam um "imperialismo do livrecomércio" em termos aceitáveis para os banqueiros e os industriais do centro capitalista.

Por fim, no entanto, a ordem liberal do séc. XIX entrou num longo período de crise. Acossado por contradições tanto econômicas como políticas que se expressavam, de um lado, numa série de pânicos, quebras e depressões e, de outro, no prolongado conflito de classes e nas lutas interimperialistas pela hegemonia global, o regime liberal colapsou no séc. XX sob a pressão de movimentos de massa, revoluções sociais e duas guerras mundiais. Carregada de contradições, a história desse regime é o tema de duas obras imponentes e, não obstante, falhas: $A$ Grande

sejam o foco do presente artigo.

9 Estou supondo que a história do capitalismo pode ser compreendida como uma sequência de regimes de acumulação na qual as possibilidades disponíveis a cada vez são delimitadas pela trajetória histórica do capitalismo até então. Dentro dessa sequência, qualquer transformação dada é operada politicamente e pode ser reportada às lutas entre proponentes de projetos diferentes. Mas a sequência também pode ser reconstruída como um processo direcional no qual cada forma anterior esbarra em dificuldades ou limites que a forma que a sucede supera ou contorna, até que também ela encontre um impasse e seja, por sua vez, substituída. À luz dessa compreensão da história do capitalismo como "equilíbrios intermitentes", é possível distinguir as lutas políticas ordinárias, as quais ocorrem em períodos de relativa estabilidade dentro dos termos de um regime dado, das lutas extraordinárias, as quais buscam transformar o regime em tempos de crise. No primeiro caso, estratos subalternos buscam usar o poder público para melhorar suas próprias condições dentro dele, enquanto as frações mais previdentes da classe dominante tentam usar aquele poder para instituir reformas fragmentárias e conformes com o sistema a fim de remendar e conciliar os pontos ásperos. Até onde os respectivos objetivos daqueles dois grupos podem ser levados a convergir, reformas fragmentárias podem servir, pelo menos por algum tempo, para neutralizar a tendência à crise que é inerente ao sistema, tornando a estabilizar, de maneira temporária, as condições políticas que o impulso do capital para a acumulação sem limites desestabilizara. Em períodos de crise, no entanto, as disfuncionalidades proliferam, excedendo as capacidades reparadoras das reformas fragmentárias e incitando demandas por uma mudança estrutural profunda. Nesses períodos, grupos concorrentes de atores sociais lutam para desenvolver e realizar seus respectivos projetos para a resolução da crise - seja engendrando um novo regime de acumulação, seja criando uma sociedade pós-capitalista. 
Transformação, de Karl Polanyi, e a seção intermediária sobre o "Imperialismo" de Origens do Totalitarismo, de Hannah Arendt. Enquanto Polanyi analisou os intratáveis conflitos políticos que atormentaram as sociedades europeias que pelejavam para proteger-se da destruição causada pelo "mercado autorregulado", Arendt dissecou as deformações políticas que castigaram os Estados europeus quando a lógica expansiva e transterritorial de seus projetos coloniais, economicamente impulsionados, esbarrou na lógica territorial da dominação política. ${ }^{10}$ Apesar de seus respectivos pontos cegos, ambos os pensadores prestaram importantes contribuições para nossa compreensão das formas historicamente específicas que a contradição política do capitalismo assumira em sua fase liberal. ${ }^{11}$

Aqui, porém, enfoco o regime de acumulação que suplantou a ordem liberal na esteira da Segunda Guerra Mundial. Essa forma estatalmente administrada de capitalismo organizava o poder público de modo diferente tanto no nível estatal como no transestatal. Não mais preocupado exclusivamente com funções de constituição da economia e de repressão, o poder estatal era agora empregado também para dirigir o desenvolvimento econômico nacional, para compensar as falhas de mercado e para administrar crises econômicas (e políticas). Tanto os “Estados de bem-estar social” do centro capitalista como os Estados desenvolvimentistas da periferia, os quais recentemente haviam se tornado independentes, assumiram essas funções, em que pese a enorme discrepância entre suas respectivas capacidades para desempenhálas. Nos países do centro, os Estados eram capazes de financiar um provimento mais ou menos generoso de bem-estar social por intermédio da tributação tanto dos trabalhadores como dos capitalistas; na periferia, os novos Estados, claudicando por força dos legados coloniais, empregavam as capacidades que pudessem reunir para promover o desenvolvimento por meio de políticas de industrialização por substituição de importações. Ambos os projetos foram moldados por uma nova ordem geopolítica estabelecida sob a hegemonia dos Estados Unidos, os quais substituíram a GrãBretanha como a principal potência responsável por assegurar as condições globais de uma onda perdurável de acumulação de capital. A dominação estadunidense trouxe a Guerra Fria, o complexo militar-industrial, guerras por procuração, bem como o regime Bretton Woods de controles de capital, o qual permitia que os Estados do centro controlassem suas moedas e, assim, lançassem mão de déficits orçamentários contracíclicos como uma ferramenta de administração de crise. Em geral, esse regime buscava reconciliar o livre-comércio internacional com a condução keynesiana e a administração de crise no nível doméstico. 0 capitalismo estatalmente administrado teve uma carreira considerável e, não obstante, relativamente curta, a saber, do

10 Polanyi (2001). Arendt (1973). Sobre o conflito entre o impulso transterritorial da acumulação ilimitada e a lógica territorial da dominação política, ver também Harvey (2014).

11 Sobre os pontos cegos/insights de Polanyi, ver Fraser (2011), Fraser (2014b) e Fraser (2013). Sobre os insights/pontos cegos de Arendt, ver Fraser (2004). 
fim da Segunda Guerra Mundial até meados dos anos 1970. Durante aqueles Trente Glorieuses, ele forneceu ao centro capitalista um crescimento consumista e uma relativa paz de classes, ao mesmo tempo que exportava golpes de Estado e ditaduras militares para a periferia.

Mas, da mesma maneira que seu predecessor, também esse regime se demonstrou insustentável em longo prazo. Atormentada por contradições econômicas e políticas que se expressavam na estagflação, de um lado, e numa crise do petróleo e numa corrida armamentista, de outro, a sociedade capitalista estatalmente administrada incubava novas formas de luta social, iniciadas nos anos 1960. Focados menos na dinâmica interna da economia capitalista que na relação dessa economia com suas condições de fundo, tais conflitos se centravam no militarismo, no imperialismo e nas assimetrias étnico-raciais e de gênero, bem como numa gramática de vida consumista, distorcida pela burocracia e pelo produtivismo. Por fim, a bordoada dupla que o regime do capitalismo estatalmente administrado apanhava da disfunção sistêmica e da confrontação política levou-o ao ponto da crise. A exemplo de seu predecessor, também a carreira desse regime, carregada de contradições, inspirou obras de teoria social imponentes, embora, em última análise, falhas, incluindo Problemas de Legitimação no Capitalismo Tardio, livro de Jürgen Habermas publicado em 1973, 12 ao qual me volto agora.

Do modo como o leio, Problemas de Legitimação no Capitalismo Tardio teoriza as contradições políticas do capitalismo estatalmente administrado. O livro começa sublinhando a mudança do papel do Estado no regime pós-liberal de acumulação. Se, no regime liberal, os Estados haviam se preocupado principalmente em constituir a economia de mercado privado e em reprimir as revoltas contra ela, eles agora se encarregavam de funções adicionais de administração de crise. Entre outras coisas, eles buscavam suavizar os ciclos de expansão/quebra por meio de gastos contracíclicos, criando um setor público que substituía, em parte, o mercado, bem como administrando as relações trabalho/capital por meio de negociações corporativistas. Escrevendo no começo dos anos 1970, Habermas supôs que essas medidas haviam conseguido domesticar as contradições econômicas do capitalismo. Com o benefício da retrospecção, sabemos que ele estava equivocado nesse ponto, já que aquelas contradições irromperam novamente logo após a publicação de seu livro. É possível argumentar, porém, que esse “equívoco" não precisa invalidar sua tese principal, qual seja: mesmo quando o regime contornou - ou, é-nos possível dizer, mesmo se tivesse contornado - a tendência à crise econômica que é inerente ao capitalismo, ele não resolveu - ou, diríamos, não teria resolvido - todas as contradições do capitalismo. Em vez disso, o que ele fez foi deslocar essas contradições, mudando

12 A edição alemã original apareceu em 1973. A tradução para o inglês sucedeu-a dois anos depois: Habermas (1975). 
o locus da crise da economia para o Estado, do campo econômico para o campo político.

Assim, o foco principal de Problemas de Legitimação no Capitalismo Tardio eram as tendências de crise política do capitalismo estatalmente administrado. Adotando a perspectiva do Estado territorial limitado (e - é possível argumentar desconsiderando a dimensão global), Habermas procedeu ao delineamento de uma contradição especificamente política endêmica no regime do pós-guerra. De um lado, o Estado assumiu a tarefa de administração de crise, efetivamente aceitando a responsabilidade por assegurar o crescimento econômico, uma distribuição relativamente legítima, níveis aceitáveis de emprego, a estabilidade de salários/ preços, o provimento de bem-estar social - questões que, antes, eram compreendidas como melhor resolvidas quando deixadas para o mercado. Por conseguinte, o Estado se abriu à possibilidade de fracasso e até - caso suas políticas rompessem limites sistêmicos - à chance de crise administrativa. De outro lado, o Estado agora dependia de consideráveis reservas de legitimação proveniente da comunidade democrática de cidadãos, já que o aumento de sua responsabilidade necessitava de um aumento do apoio público. Todavia, o caráter classista fundamental da sociedade permaneceu inalterado e, em princípio, poderia não resistir a um intenso escrutínio democrático. Assim, o Estado também namorava a possibilidade de uma crise de legitimação. Para evitar essa crise, o Estado buscava um tipo peculiar de apoio político: uma propensão para aprovar a proativa direção estatal da economia que fosse generalizada numa comunidade de cidadãos tornados pacíficos e passivos, de modo que essa comunidade não estivesse disposta a inquirir os objetivos ou as justificações reais da ação estatal. A questão para Habermas, então, era esta: Poderia o Estado obter suficiente respaldo público para exercer funções administrativas ampliadas e destinadas a preservar a dominação de classe, mas sem provocar uma crise de legitimação - isto é, sem ativar a comunidade de cidadãos e levá-la a questionar o uso do poder público em prol de interesses privados?

Para Habermas, a resposta dependia da psicologia moral e social. Ainda que inscrita nessa forma de capitalismo como uma tendência inerente, uma crise de legitimação não seria, de modo algum, garantida. Antes, essa crise só emergiria se uma crise administrativa fosse acompanhada de uma crise de motivação. Nesse caso, uma massa crítica de cidadãos rejeitaria as orientações carreiristas, consumistas e privatizadas que sustentavam sua lealdade ao regime. Sacudindo a passividade política que poupava o sistema da crítica, eles poderiam questionar a legitimidade da dominação de classe e exigir sua abolição. Para Habermas, essa possibilidade, por sua vez, dependeria da força da socialização dos cidadãos para torná-los aptos e habituados à justificação normativa das ordens institucionais às quais eles se encontrassem sujeitos. Desde que uma massa crítica retivesse a disposição para insistir 
em que a dominação fosse justificada ou abolida, uma crise tanto de motivação como de legitimação seria possível. Se, no entanto, essa orientação fosse enfraquecida ou desativada, mesmo uma crise administrativa plenamente desenvolvida não se traduziria numa crise de legitimação.

Durante algum tempo, no final dos anos 1960 e no começo dos anos 1970, as condições para uma profunda crise de legitimação pareciam estar presentes. Inaugurando uma grande onda de protesto global, a "juventude" se colocava à testa de outros estratos insatisfeitos na rejeição das satisfações consumistas privatizadas que fortificavam o capitalismo estatalmente administrado no centro, bem como na rejeição da narrativa da Guerra Fria que autorizava suas predações na periferia. A “crise de motivação" daí resultante desencadeou uma repentina e massiva onda de deslegitimação que parecia chacoalhar a ordem capitalista em seu centro. 0 que ameaçava o regime, portanto, não era uma crise econômica, mas uma crise política; não eram conflitos distributivos, mas lutas fronteiriças a respeito da estrutura institucional da sociedade capitalista. Todavia, a transformação que ocorreu em seguida não foi a que Habermas ou seus protagonistas da Nova Esquerda tinham em mente. Em vez da superação do capitalismo, o que veio a seguir foi sua reinvenção sob a nova forma globalizada e financeirizada na qual vivemos hoje.

Para preparar o terreno para a compreensão do porquê, proponho reconsiderar a relação entre crise administrativa e crise de legitimação. Investigando o elo entre essas duas faces da crise política, podemos aprender algo não só sobre o capitalismo estatalmente administrado, mas também sobre o que está acontecendo - e o que não está acontecendo - hoje. ${ }^{13}$ Relembremos que, para Habermas, uma crise

13 Embora não sejam discutidos aqui, vários outros aspectos de Problemas de Legitimação no Capitalismo Tardio recompensariam a atenção cuidadosa. Por exemplo, algumas cruciais condições de possibilidade da acumulação de capital são insuficientemente teorizadas na abordagem de Habermas. Entre elas, incluem-se as condições sociorreprodutivas e ecológicas que mencionei antes, mas também - e isto é mais diretamente relevante para nossos propósitos aqui - a configuração geopolítica que molda as capacidades dos Estados, uma questão que Habermas notou, mas deixou de investigar. Igualmente importante, a tese central concernente ao deslocamento é problemática - não apenas empiricamente, mas também conceitualmente. Essa ideia repousa sobre a interpretação marxiana ortodoxa que Habermas, noutros aspectos, rejeita: a interpretação segundo a qual a economia é a base real da propensão do capitalismo à crise, o locus de sua "contradição primária", ao passo que a contradição política é secundária, um desvio superestrutural que só começa a surtir efeito quando a contradição primária é frustrada, impedida de atingir sua expressão "natural" e direta na barafunda econômica. Essa interpretação ortodoxa não só está em desacordo com a interpretação que propus aqui, mas também é menos adequada que ela: de acordo com minha interpretação, as sociedades capitalistas incubam uma inerente tendência a desestabilizar as condições políticas de possibilidade da acumulação continuada. Nem secundária nem superestrutural, essa tendência de crise não é um mero deslocamento de uma tendência de crise prévia e mais fundamental. Em vez disso, as contradições políticas e econômicas do capitalismo são cooriginárias e internamente relacionadas umas com as outras, coimplicadas na estrutura profunda da mesma ordem social. Por último, a abordagem de Habermas poderia ser criticada por insinuar que os fracassos do capitalismo estatalmente administrado seriam devidos principalmente a equívocos técnicos, desconsiderando, dessa forma, as mudanças políticas no equilíbrio do poder de classe. 
administrativa se traduz numa crise de legitimação se e somente se ela passa pelo intermediário de uma crise de motivação. A ideia geral é bastante persuasiva: as disfunções no nível sistêmico nunca ditam, por si próprias, as respostas dos atores sociais. Mas a explicação que Habermas dá das mediações entre aquelas disfunções e estas respostas é inadequada - sustento - porque exclusivamente focada na psicologia moral. Do modo como o compreendo, o fator decisivo seria a força da disposição de uma população para exigir uma justificação normativa dos arranjos sociais aos quais ela está sujeita. Mas tal disposição, ainda que forte, não é suficiente para garantir uma crise de legitimação. Essa crise requer algo mais - algo substantivo e distintivamente político. ${ }^{14}$

Para entender esse “algo", poderíamos voltar-nos àquele que é o mais político dos pensadores marxistas, a saber, Antonio Gramsci. O pensamento de Gramsci, frequentemente visto como antitético ao de Habermas, apresenta um par de conceitos - hegemonia e contra-hegemonia - que proveem as mediações políticas faltantes entre as crises administrativa e de legitimação. Do modo como compreendo esses conceitos, hegemonia é a face discursiva da dominação, o processo pelo qual uma classe dominante estabelece sua autoridade e naturaliza sua dominação por meio da instalação das pressuposições de sua própria visão de mundo como o senso comum da sociedade como um todo. Contra-hegemonia, por sua vez, é a face discursiva de uma oposição que é suficientemente robusta e autoconfiante para montar uma abrangente contestação das suposições dominantes acerca da realidade social (Gramsci, 1971). O que baseia as visões de mundo hegemônicas - e suas rivais contra-hegemônicas - são suposições sobre as posições de sujeito e as capacidades de agir disponíveis para os atores sociais; sobre as responsabilidades próprias e as reais capacidades [capabilities] dos poderes públicos; sobre a estrutura e o funcionamento da ordem social reinante; sobre os princípios e os enquadramentos de justiça com base nos quais aquela ordem deve ser avaliada; e sobre a disponibilidade histórica de alternativas desejáveis e realizáveis. ${ }^{15}$ É o conjunto das suposições arraigadas sobre essas questões, enquanto embutidas no senso comum, que molda as respostas dos atores sociais às "perturbações sistêmicas". O que determina se uma crise administrativa se torna numa crise de legitimação é não apenas uma disposição abstrata para a justificação normativa, mas o modo concreto pelo qual essa disposição é instanciada por via de suposições do senso comum a respeito do agir, do poder público, da sociedade, da justiça e da história.

O que, no senso comum político dos anos 1970, possibilitava a passagem de uma crise administrativa para uma crise de legitimação? Minha leitura de Habermas sugere

14 Para um argumento semelhante, ver Azmanova (s. n.).

15 A proposta de centrar as análises da hegemonia/contra-hegemonia em suposições a respeito do agir, dos poderes públicos, da sociedade, da justiça e da história é minha, não de Gramsci. 
uma resposta nuançada. Quanto à capacidade de agir, os sujeitos do capitalismo estatalmente administrado eram interpelados, acima de tudo, como consumidores privados no mercado e como clientes individuais do Estado de bem-estar social, e não como agentes coletivos da autodeterminação; ainda que permanecessem circulando antigos idiomas que atrelavam a cidadania à capacidade de agir politicamente, sua função no regime era, sobretudo, retórica. Todavia, os cidadãos do centro se encontravam preparados para pensar que seus Estados tinham a capacidade de tratar de seus problemas, bem como a responsabilidade por fazê-lo; assim, eles estavam dispostos a considerar que seus Estados deviam prestar-lhes contas da não realização do que prometiam. ${ }^{16}$ Por conseguinte, o regime institucionalizava uma visão complexa da sociedade, cuja estabilidade requeria a cuidadosa imbricação e equilibração entre o poder público e o poder privado; somente uma ativa direção estatal da economia capitalista que permitisse uma ampla iniciativa empresarial poderia assegurar níveis de consumo doméstico e taxas de lucro empresarial que satisfizessem as firmes expectativas dos estratos envolvidos. Igualmente importante era o fato de que o regime institucionalizava duas compreensões da justiça distributiva que, além de diferentes, eram potencialmente conflitantes: as normas libertárias endossavam os resultados das transações "voluntárias" no mercado, ao passo que os ideais de cidadania social autorizavam o poder público a fazer uma redistribuição "igualitária" dentro dos limites do enquadramento nacional. ${ }^{17}$ Por último, os atores sociais eram estimulados, em todo "o mundo livre", a defender as liberdades e a prosperidade das quais gozavam contra a ameaça comunista; assim, embora existisse uma alternativa histórica ao capitalismo, sua caracterização como "totalitária" servia para demonizar até as formas democráticas de radicalismo antissistêmico.

Em geral, portanto, o senso comum político do capitalismo estatalmente administrado dispunha seus sujeitos a uma relativa quiescência, mesmo em face do fracasso administrativo. Todavia, esse senso comum não era unidimensional. Sendo uma formação de compromisso nascida das lutas de um período anterior, suas noções dominantes de capacidade de agir, poder, sociedade, justiça e história eram "internamente dialogizadas", para usar uma expressão de Mikhail Bakhtin (1986). Atravessado por referências a suposições alternativas, o imaginário político hegemônico acomodava em si mesmo um potencial contestatório subliminar. Esse potencial poderia, em princípio, ser ativado pela agitação contínua de determinados ativistas que propagavam interpretações contra-hegemônicas que, por sua vez, poderiam alcançar alguma aceitação ao se basearem em compreensões que já

16 Tais suposições podem muito bem ter parecido mais incertas para alguns habitantes da periferia, cuja continuada sujeição a uma ordem geopolítica neoimperial era difícil de ignorar.

17 A contraditória copresença dessas duas compreensões da justiça no senso comum do capitalismo estatalmente administrado é notada por Streeck (2011). O enquadramento das questões de justiça é discutido em Fraser (2005) e Fraser (2008). 
estavam disponíveis de modo latente.

Algo parecido estava, de fato, ocorrendo durante o período no qual Habermas escrevia Problemas de Legitimação no Capitalismo Tardio. Foi nesse período que os membros da Nova Esquerda se puseram a explorar as brechas do senso comum oficial do capitalismo estatalmente administrado a fim de construir um prisma alternativo para a avaliação da legitimidade do regime. Recorrendo a antigas tradições do pensamento republicano, eles mobilizavam interpretações contra-hegemônicas da capacidade de agir que valorizavam a "participação" para condenar a subjetivação consumista e clientelista no capitalismo estatalmente administrado; com efeito, eles interpelavam os sujeitos subalternos como cidadãos ativos. Da mesma forma, os protagonistas de 1968 recorriam à compreensão relativamente ampla que o regime tinha do escopo da responsabilidade pública, repudiando, no entanto, sua identificação com a burocracia e o militarismo; rejeitando tanto o "controle social expertocrático" como o imperialismo que grassava na Guerra Fria, eles buscavam reimaginar o poder público em termos de democracia participativa e libertação nacional. $E$ mais, os radicais também expunham o suposto equilíbrio do capitalismo estatalmente administrado como profundamente desequilibrado; dando conta de que o capital ficava com a parte do leão dos benefícios de sua parceria com o Estado, eles punham a nu um sistema social no qual o poder público era empregado, de modo rotineiro, em prol do interesse privado. Condenando tal sociedade, os membros da Nova Esquerda também repensavam e davam novo enquadramento às interpretações hegemônicas da justiça social; rejeitando a interpretação libertária, eles buscavam combinar uma compreensão ampliada da cidadania social (expandida para além do enquadramento nacional e aplicada às clivagens de gênero, nacionalidade e "raça"etnicidade, bem como à classe) com seus próprios ideais democrático-radicais de igual participação e não dominação. Por último, os radicais dos anos 1960 repudiavam a limitação, corrente na Guerra Fria, da possibilidade histórica à escolha impalatável e dura entre capitalismo estatalmente administrado e comunismo "totalitário"; reimaginando a história como um campo aberto de possibilidades que estão a desenvolver-se, eles insistiam no direito e, aliás, no dever de inventar alternativas mais justas e democráticas. Tudo tomado em conta, a agitação da Nova Esquerda pareceu, por um momento, conseguir construir um senso comum contra-hegemônico. Sob a pressão de sua mobilização, os fracassos administrativos do capitalismo estatalmente administrado provocaram, de fato, uma crise de legitimação.

Na seção seguinte, consideraremos como precisamente essa crise de legitimação foi, afinal, resolvida. Primeiro, porém, permitam-me concluir a presente discussão reafirmando a ideia principal. Uma teoria crítica das contradições políticas do capitalismo está bem servida pela distinção habermasiana entre crise administrativa e crise de legitimação. Ao introduzir certo espaço entre as disfunções sistêmicas 
e as respostas dos atores sociais, sua abordagem nos convida a considerar se, sob um conjunto dado de condições, os fracassos administrativos tendem a levar à quiescência ou ao ativismo transformador. Não obstante, uma compreensão completa da relação entre crise administrativa e crise de legitimação requer uma mediação especificamente política. Para prover esse elo, recorri à concepção de Gramsci de hegemonia como senso comum político. Composto de suposições historicamente específicas sobre a capacidade de agir, o poder público, a sociedade, a justiça e a história, esse conceito provê a mediação política faltante entre as duas dimensões da crise, a sistêmica e a relativa ao mundo da vida. Coloquemos agora esses conceitos para trabalhar em nossa tentativa de teorizar as contradições políticas do capitalismo financeirizado contemporâneo.

\section{Contradições políticas do capitalismo financeirizado}

A crise de legitimação do regime estatalmente administrado foi resolvida, conforme observei antes, não pela superação do capitalismo, mas por sua reinvenção. No regime subsequente, o qual chamo de capitalismo financeirizado, ${ }^{18}$ os bancos centrais e as instituições financeiras globais substituíram os Estados como os árbitros de uma economia cada vez mais globalizada. São eles, e não os Estados, que agora produzem uma grande parte das regras que governam as relações centrais da sociedade capitalista: as relações entre trabalho e capital, cidadãos e Estados, centro e periferia, bem como as relações - cruciais para todas as relações anteriores entre devedores e credores. As últimas são centrais para o capitalismo financeirizado e permeiam todas as outras. Agora, é principalmente através da dívida que o capital canibaliza o trabalho, disciplina os Estados, transfere riqueza da periferia para o centro e suga valor da sociedade e da natureza. Como a dívida flui entre Estados, regiões, comunidades, famílias e empresas, ${ }^{19}$ o regime está reconfigurando as divisões constitutivas do capitalismo, a saber, as divisões entre economia, política, sociedade e natureza. O resultado é a ampliação da dominação do capital sobre suas condições de possibilidade de fundo: sobre a reprodução social, sobre o ambiente natural e - o mais importante para nossos propósitos aqui - sobre os poderes públicos que sempre foram indispensáveis a uma economia capitalista.

18 Emprego a expressão "capitalismo financeirizado" para designar o atual regime do capitalismo como uma ordem social institucionalizada. Assim como a expressão "capitalismo estatalmente administrado", a qual the é a contraparte, ela nomeia um modo distintivo e historicamente específico de institucionalizar as divisões constitutivas do capitalismo, a saber, as divisões entre política/economia, produção econômica/reprodução social e sociedade/natureza. Por outro lado, emprego o termo "neoliberalismo" para designar um complexo ideológico que retrata o regime capitalista financeirizado como natural, justo, eficiente e gerador de prosperidade, destinado a assegurar a maior felicidade do maior número.

19 Para uma explicação do alastramento dos fluxos financeiros por praticamente todos os espaços sociais e todas as instituições no atual regime, ver Lapavitsas (2014). 
De fato, o capitalismo financeirizado alterou profundamente a relação anterior da economia com a política. Enquanto o regime precedente investiu os Estados de poder para subordinar os interesses de curto prazo das empresas privadas ao objetivo de longo prazo da acumulação continuada, o presente regime autoriza o capital financeiro a disciplinar os Estados e os públicos em prol dos interesses imediatos dos investidores privados. O resultado é um duplo tanglomanglo. De um lado, as instituições estatais que antes eram (um tanto) receptivas às questões dos cidadãos são cada vez menos capazes de resolver seus problemas ou de satisfazer suas necessidades. De outro lado, os bancos centrais e as instituições financeiras globais que agora constrangem as capacidades estatais são politicamente independentes - não prestam contas aos públicos e são livres para agir em prol de investidores e credores. Enquanto isso, a escala dos problemas prementes, tais como o aquecimento global, excede o alcance e o peso dos poderes públicos. Esses poderes, em todo caso, são superados pelas empresas transnacionais e pelos fluxos financeiros globais, os quais escapam ao controle das agências políticas acorrentadas a um território limitado. O saldo final é uma crescente incapacidade dos poderes públicos de colocar rédeas nos poderes privados. Daí a associação do capitalismo financeirizado com a “desdemocratização" e a "pós-democracia” - uma associação que agora se revela como sistêmica.

Até a presente data, falta-nos uma explicação abrangente do capitalismo financeirizado que seja comparável, em profundidade histórica e poder analítico, às explicações dos regimes anteriores feitas por Polanyi e Habermas. Mas pensadores como Crouch, Streeck, Brown, Harvey, Sassen, Lapavitsas e Gill apreenderam elementos importantes do novo regime. Valendo-nos de suas obras, podemos reunir os rudimentos de uma explicação mais completa.

Comecemos com a ordem internacional, cuja transformação desencadeou a ascensão do capitalismo financeirizado. Elementos centrais da estrutura de Bretton Woods, os quais haviam sustentado o regime anterior, foram desmantelados nos anos 1970; a abolição das taxas de câmbio fixas e a conversibilidade do dólar em ouro abriram as comportas da especulação global. Além disso, o Banco Mundial e o Fundo Monetário Internacional foram submetidos a uma reorientação que os tornou em agentes da liberalização econômica. Por último, novos tratados internacionais, tais como o NAFTA, e novas organizações intergovernamentais, tais como a OMC, erigiram o "livre-comércio" e a "propriedade privada" em trunfos globais que passam por cima dos direitos domésticos trabalhista e ambiental.

A potência que moldou a nova ordem amiga das finanças foram os Estados Unidos. Supervisionando a transição para o novo regime, eles também prolongaram sua hegemonia, a qual se mantém mesmo hoje em dia, quando a Guerra Fria cede lugar à Guerra ao Terror. Apesar da considerável perda de autoridade moral e de 
uma mudança em seu status que os fez passar de nação credora a nação devedora, os Estados Unidos ainda servem como o possibilitador e executor global do capital, recorrendo, de modo alternado, à força das armas, à clava da dívida e às lisonjas do comércio ao se empenharem para globalizar e liberalizar a economia mundial, agora ampliada para incluir aquela que já foi a esfera comunista.

A nova ordem global redefiniu as fronteiras entre economia e política em todos os níveis. Na periferia, seus agentes sujeitaram o Estado desenvolvimentista a um assalto feroz. A princípio, a América Latina tornou-se refém do "Consenso de Washington", tendo as ditaduras apoiadas pelos Estados Unidos iniciado o processo de abertura de mercados e de privatização de ativos. Posteriormente, o Fundo Monetário Internacional e o Banco Mundial impeliram a mesma agenda em boa parte do Sul Global, agora sob o banner do "ajuste estrutural”. Por meio de cláusulas condicionais de contratos de empréstimo, tais instituições compeliram os Estados pós-coloniais precisados de dinheiro a abandonar as protegidas praias da substituição de importações pelas águas infestadas de tubarões do mercado global. Os Estados endividados, porém, não se mantiveram meramente passivos. Pelo contrário, eles desenvolveram, de modo ativo, estratégias para assegurar uma moeda forte, incluindo a promoção da emigração de trabalhadores de olho nas remessas de dinheiro, bem como o namoramento de investimentos estrangeiros diretos por meio da criação de zonas de processamento de exportação.

Esses arranjos serviram para facilitar outra característica definidora do capitalismo financeirizado: a transnacionalização da produção. Ao deslocarem a manufatura para a semiperiferia, as empresas fizeram mais do que meramente diminuir seus custos salariais e tributários e escapulir de regulações. Além disso, elas se beneficiaram de uma grande mudança no contrapeso que o poder privado exerce para o poder público, bem como contribuíram para tal mudança. Destroçando sindicatos poderosos no centro capitalista, a "desindustrialização" enfraqueceu ali o apoio à social-democracia, ao mesmo tempo que iniciou uma corrida para o fundo do poço na periferia, corrida que incrementou o poder do capital em todo o mundo. Por conseguinte, os países do Sul Global que haviam começado a industrializarse recentemente estão agora submersos em sweatshops, poluição e megafavelas produzidas pela expropriação, via endividamento, das massas de camponeses. Enquanto isso, as cidades desindustrializadas do centro - outrora domicílio de consideráveis concentrações de patrimônios empresariais tributáveis, bem como domicílio de empregos com salários que conseguiam sustentar uma família inteira agora dependem cada vez mais de dívidas com juros altos e de trabalhos precários e mal remunerados no setor de serviços, trabalhos que, amiúde, são desempenhados por mulheres, ao passo que os cortes no provimento de bem-estar social requerem mais trabalho familiar não pago. Por último, os corredores do Cinturão do Sol nutrem 
uma simbiose de empresas de alta tecnologia, universidades convertidas em empresas e capital de risco, enquanto as "cidades globais" são dominadas pelas finanças, pelo trabalho mal pago no setor de serviços e pelos valores astronômicos dos imóveis. ${ }^{20}$ Nesse novo nexo entre economia e política, as conhecidas formas de acumulação via exploração do trabalho se entrelaçam com formas novas, financeirizadas, de acumulação por expropriação. ${ }^{21}$

Igualmente transformadora foi a progressiva abolição dos controles de capital, abolição que remodelou ainda mais o nexo entre economia e política em benefício do capital. Essa alteração no regime global liberou vultosos fluxos financeiros para perseguirem o "spread" lucrativo, privando os Estados, dessa maneira, do controle sobre suas moedas. O resultado foi a desativação de uma crucial ferramenta keynesiana de administração de crise - pelo menos para Estados que não sejam os Estados Unidos, estes podendo simplesmente pôr-se a imprimir mais dos dólares que servem como a "moeda mundial". Nos demais Estados, os governos devem estabelecer as políticas social e fiscal de olho nos mercados de títulos e nas agências de avaliação, as quais olham com desconfiança para gastos deficitários destinados a "aquecer a economia" ["prime the pump"]. Tais dificuldades foram consideravelmente pioradas pela introdução do Euro em 1999, conforme veremos. Em consequência, os Estados do centro são empurrados para uma posição de há muito familiar aos Estados da periferia: sujeição a forças econômicas globais que eles não podem sequer ter a esperança de controlar.

Durante algum tempo, os governos impedidos de lançar mão de políticas keynesianas tradicionais voltaram-se para o que Colin Crouch chamou de "keynesianismo privatizado" (Crouch, 2009). Eles encorajaram o endividamento do consumidor (financiamento do lar mediante hipoteca, cartões de crédito, empréstimos para estudantes universitários, financiamento de automóvel, linhas de crédito mediante o oferecimento de imóvel quitado como garantia) a fim de manter elevados níveis de consumo em condições que normalmente seriam desfavoráveis: queda dos salários reais, alta do desemprego e da precariedade e declínio das receitas tributárias, a última cortesia de uma revolta tributária conduzida, de modo coordenado e militante, pelas empresas e pelos ricos, conforme documentado por Wolfgang Streeck (2014). Essa política de consumismo alimentado pelo endividamento promoveu um novo round do "privatismo cívico" que Habermas identificara no regime anterior. Por meio do encorajamento dos cidadãos a centrar suas aspirações na vida privada e nas satisfações mercadorizadas, logrou-se uma legitimação política

20 Sobre as cidades globais, ver Sassen (2005). Sobre os desenvolvimentos correspondentes no Sul Global, ver Sassen (2000).

21 Sobre a distinção entre acumulação por exploração e acumulação por expropriação, ver Harvey (2014). Para uma explanação dessa distinção que seja conciliável com a compreensão ampliada (não economicista) do capitalismo elaborada aqui, ver Fraser (2014a). 
que era convenientemente passiva mesmo em face de políticas redistributivas em favor dos de cima, políticas que normalmente poderiam ter desencadeado enérgicos protestos (Streeck, 2012). Engordando os cofres das finanças e, simultaneamente, esgotando o tesouro público, essa política também serviu para justificar mais cortes no provimento de bem-estar social.

Ao menos por um momento, a crise financeira de 2008 teve um efeito negativo sobre o keynesianismo privatizado. Mas, longe de atenuar o controle exercido pelas finanças, seu efeito foi a solidificação do poder das dívidas sobre as condições de fundo do capital, especialmente sobre o poder público e a reprodução social. Face a face com a crise iminente, os bancos centrais e as instituições financeiras globais pressionaram os Estados a proceder, às expensas dos cidadãos, ao resgate financeiro dos investidores. Em vários casos, os governos obedientes despencaram diretamente em crises da dívida soberana. Especialmente na Zona do Euro, os efeitos foram catastróficos. Privados da possibilidade de desvalorização, os Estados-membros endividados que se encontravam sob o assalto dos mercados de títulos foram compelidos a instituir a austeridade, destruindo as fontes de sustento e os mundos sociais de bilhões de pessoas. Ignorando os protestos dos cidadãos e nulificando os resultados eleitorais contra a austeridade, a soberana "Troika" canalizou para os investidores privados cada uma das derradeiras gotas de valor que podiam ser extraídas das populações devastadas. O impacto sobre a legitimidade da União Europeia foi dramático. Uma "comunidade" outrora considerada como a encarnação da democracia pós-nacional revelava-se agora como a serva das finanças.

De modo mais geral, o capitalismo financeirizado é a era da "governança sem governo" - isto é, da dominação sem a folha de figo do consentimento. Nesse regime, são as estruturas de governança transnacional, tais como a Organização Mundial do Comércio, e não os Estados, que criam uma parcela cada vez maior das regras coercitivamente executáveis que agora regem extensas faixas de interação social em todo o mundo. É certo que essas estruturas foram construídas pelos governos - ou melhor, pelos governos dos Estados mais poderosos, os quais, subsequentemente, constrangeram os governos de outros Estados a juntar-se a eles -, e também é certo que os governos devem aceitar e fazer cumprir as disposições jurídicas de tais estruturas. Mas, se isso é suficiente para qualificá-los como "públicos", esses organismos não prestam contas aos públicos democráticos e estão determinados a eliminar sua influência. Operando principalmente a portas fechadas e esmagadoramente no interesse do capital, acordos como NAFTA e TRIPS ("sobre Aspectos dos Direitos de Propriedade Intelectual Relacionados ao Comércio") estão cravando as políticas macroeconômicas neoliberais no coração da economia global de modo a evitar que elas venham a ser revertidas pela ação política futura. ${ }^{22}$ Criando o que Stephen 220 mesmo vale para a Parceria Transpacífico (TPP), pendente de conclusão, e para acordos de livre- 
Gill chama de um "novo constitucionalismo" destinado a reduzir o alcance da política democrática, tais acordos estabelecem firmemente o "livre-comércio" e os "direitos de propriedade" (privada) como trunfos que impedem que as leis criadas democraticamente restrinjam a liberdade do capital para abusar do trabalho e para pilhar o meio ambiente (Gill, 1998). Na medida em que normas neoliberais são “constitucionalizadas", a agenda política é estreitada, bloqueada de antemão.

Por último, o novo regime promove a captura do poder público pelo poder privado (empresarial) em todos os níveis. Os exemplos mencionados por Crouch incluem um aumento das pressões lobistas abertas e encobertas; a porta giratória entre o governo e as empresas privadas, a qual assegura que os representantes dos interesses privados redijam as próprias regulações às quais estão sujeitos; a cessão contratual de serviços públicos a empresas privadas por extenso prazo (incluindo, nos Estados Unidos, a gestão prisional e funções militares), sendo o desempenho delas monitorado não pelo controle político público, mas pelo direito contratual privado; a ascensão das "parcerias público-privadas" orientadas a servir aos "consumidores", em oposição aos cidadãos, as quais mudam o sentido qualitativo e o caráter dos serviços públicos; e a "nova administração pública”, a qual exige das agências públicas que imitem as práticas supostamente superiores das grandes empresas privadas - por exemplo, construindo "centros de ganhos/perdas" internos que "compitam” por alocações orçamentárias base zero (Crouch, 2011). Dessas e doutras maneiras, o poder público é internamente colonizado. Recorrendo a noções foucaultianas de governamentalidade, pensadores como Wendy Brown e Pierre Dardot e Christian Laval descreveram perspicazmente importantes elementos dessa “racionalidade política neoliberal” (Brown, 2015; Dardot \& Laval, 2013).

O saldo final é o esvaziamento da democracia em todos os níveis. As agendas políticas são estreitadas em todo o mundo, tanto por injunção externa (as demandas dos “mercados", “o novo constitucionalismo") como por cooptação interna (captura empresarial, subcontratação, a disseminação da racionalidade política neoliberal). Questões outrora consideradas como diretamente dentro do alcance da ação política democrática são agora declaradas como para além de seus limites e delegadas aos "mercados" - para benefício das finanças globais e do capital empresarial. A resposta àqueles que questionam esses arranjos é NHA: “não há alternativa”. A política deve adaptar-se às leis da economia. No admirável mundo novo do capitalismo financeirizado, os poderes públicos não podem prover soluções àqueles em cujo nome governam. Assim, a desdemocratização, em vez de um desenvolvimento contingente, é estrutural, embutida no DNA desse regime.

Consideremos que isso seja suficiente, por ora, como uma descrição analítica do novo nexo economia/política no capitalismo financeirizado. Ao menos

comércio projetados pela União Europeia. 
teoricamente, trata-se de um arranjo que está criando problemas para si mesmo. Como vimos, uma ordem institucional que tenta liberar a economia da política corre o risco de desestabilizar os poderes públicos dos quais o capital precisa para afiançar um duradouro período de acumulação. Ao esvaziar suas capacidades de ação pública, tal regime destrói sua aptidão para desativar bombas-relógios que, tais como o aquecimento global e o mercado de derivativos financeiros, colocam em perigo as chances de longo prazo do desenvolvimento capitalista. O efeito poderia ser uma grande crise sistêmica, uma vez que a fera continua a devorar seu próprio rabo. ${ }^{23}$ No mínimo, tais arranjos se encontram preparados para produzir uma crise administrativa, uma vez que os poderes públicos se tornam cada vez mais incapazes de prover os resultados dos quais o capital - assim como o resto de nós - precisa. $\mathrm{E}$ isso, por sua vez, poderia desencadear uma crise de legitimação na qual a opinião pública se voltasse contra um sistema disfuncional e clamasse por transformação social.

Em nosso tempo, o capitalismo financeirizado, de fato, deu origem a uma aguda crise administrativa. Mas ele também desencadeou uma crise de legitimação? É certo que nossas instituições enfrentam déficits de legitimação em todas as escalas. Mas déficit de legitimação não é o mesmo que crise de legitimação. Essa crise depende, como vimos, das mediações entre "sistema" e "mundo da vida". Ela depende, sobretudo, do senso comum político por intermédio do qual as disfunções sistêmicas são experienciadas e interpretadas pelos atores sociais. Como esse senso

23 Neste ponto, alguém poderia levantar a seguinte questão: o capitalismo financeirizado está destruindo o poder público enquanto tal ou apenas o poder público democrático? No primeiro caso, o capital estaria esvaziando a política per se, despachando a relativa independência dela em relação à economia e tornando-a um instrumento do capital simpliciter. No segundo caso, ele estaria criando uma nova forma de governança transnacional que reteria a capacidade de disciplinar o capital e, ao mesmo tempo, descartaria toda aparência de legitimidade democrática. No primeiro cenário, o capitalismo financeirizado namora a crise ao erodir o próprio poder público do qual o capital necessita para sustentar o processo de acumulação em longo prazo. No segundo cenário, o regime poderia evitar a crise, pois reteria uma capacidade de governança suficiente para amarrar o capital ao mastro da regulação política e, assim, salvá-lo dele mesmo. Se o primeiro cenário soa mais catastrófico que o segundo, ele também parece mais provável. E ele certamente será o cenário efetivo se as atuais práticas de regulação transnacional da atividade empresarial apresentarem algum grau de eficácia, pois elas raramente subordinam os lucros de curto prazo à estabilidade de longo prazo, se é que alguma vez o fazem. Tampouco é claro se o poder público vislumbrado no segundo cenário poderia possuir, de fato, o peso necessário para disciplinar o capital. Ausente o input democrático, faltaria ao regime hipoteticamente concebido um contrapoder que se opusesse ao poder do capital no curso ordinário do vale-tudo político. Tampouco tal regime poderia, sem correr o risco da revolta, mobilizar energias populares para fazer com que passassem as reformas destinadas a salvar o sistema em conjunturas críticas. Nessas situações, seu único recurso concebível seria a força militar - um recurso ainda ciosamente monopolizado pelos Estados territoriais e cuja cessão a organizações transnacionais para fins de restrição da atividade empresarial é improvável. Assim, mesmo nesse que é o melhor cenário possivel (quer dizer, melhor para a estabilidade sistêmica), seria improvável escapar das tendências do capitalismo financeirizado à autodesestabilização. 0 capitalismo financeirizado parece estar criando problemas para si mesmo em ambos os casos. Sou grata a Bill Scheuerman por levantar a questão que me levou a tomar em consideração o segundo cenário. 
comum se apresenta hoje?

Para compreendê-lo, relembremos a crise dos anos 1970. Naquela época, como vimos, a Nova Esquerda montou uma contestação contra-hegemônica das suposições sobre capacidade subjetiva de agir, poder público, sociedade, justiça e história que reinavam no capitalismo estatalmente administrado. Essa contestação demonstrouse suficientemente poderosa para deslegitimar tal regime, mas não suficientemente poderosa para determinar a direção básica de sua transformação. Ao invés disso, as suposições da Nova Esquerda foram, elas mesmas, hegemonizadas, recuperadas dentro de um novo senso comum emergente que agora permeia o capitalismo financeirizado.

Frequentemente descrito como "neoliberal", o novo senso comum é internamente dialogizado. Assim como o senso comum do regime predecessor, também ele incorpora traços de lutas anteriores e referências a visões de mundo alternativas. 0 entrelaçamento aqui, porém, é entre suposições liberais parcialmente desacreditadas no capitalismo estatalmente administrado, mas agora reinventadas, e elementos do radicalismo dos anos 1960 que, a princípio, ajudaram a desacreditar o capitalismo estatalmente administrado, mas, desde então, foram remodelados por aquelas suposições liberais. Produzido nas contracorrentes nas quais os "novos movimentos sociais" que sucederam à Nova Esquerda encontraram a maré crescente do liberalismo ressurgente, esse amálgama mescla os restos da crítica de 1968 ao clientelismo e à burocracia com um novo/velho romance do empreendedorismo. 0 resultado é um "novo espírito do capitalismo" que funde o carisma de 1968 com a aura de 1989, ao mesmo tempo que empresta um frisson de excitação emancipatória ao trabalho repetitivo e enfadonho da acumulação sem fim (Boltanski \& Chiapello, 2006).

Esse amálgama marca todos os principais elementos do senso comum político no capitalismo financeirizado. Com respeito à capacidade de agir, os sujeitos desse regime são interpelados como centros autônomos de iniciativa, a antítese dos "clientes passivos" do capitalismo estatalmente administrado. Mas a autonomia é figurada como privada e centrada na "escolha" e na "responsabilidade pessoal". Despojada de conotações políticas públicas, a liberdade adquire uma aparência economicista, antigos motivos consumistas sendo atrelados a tropos mais recentes que enaltecem os sujeitos como possuidores de capital humano, por cuja administração e maximização eles são responsáveis. Esse modo empreendedor de subjetivação (Brown, 2015; Dardot \& Laval, 2013) anda de mãos dadas com uma visão pejorativa do poder público, figurado como inerentemente opressivo e ineficiente, inferior às empresas privadas. Com efeito, a crítica da Nova Esquerda à burocracia é desvestida de seu ethos participativo e entrelaçada à crítica thatcherista ao "Estado babá"; e as aperturas do regime anterior são atribuídas ao excessivo alargamento do poder 
público para além de limites próprios. Assim, o atual senso comum tenta liberar a economia da política, ao mesmo tempo que insiste (de novo, com Thatcher) em que "não existe essa coisa de sociedade". Essa visão encontra apoio em modismos intelectuais atuais - primeiro, na teoria da escolha racional, a qual reduz processos sociais de média e larga escala a transações de pequena escala entre indivíduos; e, segundo, em correntes do pensamento pós-estruturalista que invocam a ubiquidade do "discurso" para desautorizar a análise institucional e a crítica estrutural. ${ }^{24}$ Tendo descartado a ideia de sociedade, o senso comum neoliberal fornece uma visão da justiça que é individualista e centrada no mercado. Repudiando tanto os princípios de cidadania social que autorizam a redistribuição como os ideais democráticoradicais de não dominação, a visão hegemônica sustenta que a única distribuição justa é aquela que resulta de transações no mercado que sejam voluntárias, não distorcidas pela negociação coletiva nem pela interferência estatal. Em tal mundo, os indivíduos recebem exatamente o que merecem; pequenos quinhões refletem talentos irrisórios ou esforços débeis. Embora essa visão represente a antítese do pensamento da Nova Esquerda, ela permanece, em larga medida, não contestada pelos movimentos que sucederam à Nova Esquerda - ou antes, por duas das principais correntes desses movimentos: primeiro, pelas vertentes identitárias que abandonam o terreno da (in)justiça distributiva para focar-se unilateralmente no terreno do (não) reconhecimento; e, segundo, pelas vertentes desassombradamente liberais que identificam a emancipação com o florescimento das empresas - a exemplo dos feminismos liberais que visam "fazer acontecer" e "rachar o teto de vidro" (Fraser, 2009). Entre as vertentes identitárias e liberais dos novos movimentos sociais, pouco resta da mentalidade radical de outrora que pudesse exercer oposição aos ideais hegemônicos da "justiça de mercado". Por fim, causa alguma surpresa o fato de o senso comum neoliberal adotar uma visão estreita da possibilidade histórica? Retratando o socialismo como irremediavelmente desacreditado, esse senso comum interpreta a sociedade capitalista como o fim da história.

Ao menos à simples vista, o senso comum político de nosso tempo oferece aos sujeitos do capitalismo financeiro poucos recursos interpretativos para a mobilização transformadora. Ao invés disso, ele se articula facilmente, se não com total concordância, com nacionalismos e racismos retrógrados, os quais usurpam muito do espaço discursivo para o exercício da oposição. A articulação é feita pelo modo empreendedor de subjetivação descrito há pouco. 0 mesmo gesto que define o bom sujeito como aquele(a) que maximiza seu capital humano também gera, como seu lado $B$, ícones racializados do agir defeituoso e da irresponsabilidade pessoal por exemplo, os gregos, indigitados como muito precocemente aposentados, ratos

24 Para uma interessante explicação de como a teoria da escolha racional e o pós-estruturalismo convergem na dissolução da sociedade, ver Rodgers (2011). 
de praia, sonegadores, esbanjadores e extravagantes, servem para muitos europeus setentrionais como os equivalentes funcionais das welfare queens que costumavam assombrar o imaginário político do capitalismo estatalmente administrado nos Estados Unidos. ${ }^{25}$ Tais noções alimentam facilmente as distrações da produção de bodes expiatórios, incentivando a substituição de uma crítica institucional-estrutural de um sistema em crise por antagonismos político-identitários. ${ }^{26}$ Elas também fornecem um conveniente ponto de apoio para a expansão do poder repressivo que é parte essencial de toda crise, inclusive a presente, malgrado a crítica neoliberal ao poder público. ${ }^{27}$

Mas o senso comum neoliberal não é plenamente consistente. Essa configuração incuba elementos subordinados e latentes que poderiam, em princípio, ser ativados num esforço contra-hegemônico. Especialmente promissores são aqueles elementos residuais do pensamento da Nova Esquerda que foram atualmente recuperados numa roupagem neoliberal, mas que estão potencialmente disponíveis para uma ressignificação. Por exemplo, o ideal inerentemente ambivalente de um sujeito autônomo e ativo poderia ser despido de suas conotações empreendedoras e remodelado democraticamente, em termos de coparticipação em práticas coletivas de liberdade política. Nesse caso, a ideia atualmente desacreditada de poder público poderia ser revalorizada - purgada de suas associações estatistas e aliada a projetos de democratização transnacional destinados a criar novas capacidades públicas para tratar de problemas transterritorais no interesse público e em conformidade com a prestação de contas democrática. ${ }^{28}$ De modo semelhante, o conceito de sociedade capitalista poderia ser resgatado das recentes desconstruções culturalistas e economicistas e

25 Sobre a pré-história desse aspecto da subjetivação neoliberal, ver Fraser \& Gordon (2013).

26 Seria possível citar muitas outras noções semelhantes, tais como a invasão de encanadores poloneses sub-remunerados que já foi temida na França; as vítimas do patriarcado islâmico que, vestidas de burca e iludidas, agora são deploradas ali; e tomadores de empréstimo subprime que intentam viver acima do padrão que lhes é acessível. A lista continua.

27 Certamente, a presente crise está ensejando uma grande expansão do poder repressivo do Estado. Tomemos em consideração a criação de vastos projetos de vigilância eletrônica e a implacável persecução penal dos denunciantes que os expuseram, indigitados como "traidores" e "espiões"; o aumento da militarização tanto do policiamento como da "defesa" das fronteiras; a expansão de prisões, instalações de detenção, black sites (campos de tortura) e centros de internamento no estrangeiro para requerentes de asilo; os cortes por atacado das liberdades civis e políticas em nome do antiterrorismo. Essa intensificação e alargamento do poder repressivo do Estado ocorre ao mesmo tempo que outras funções estatais estão sendo eliminadas, diminuídas, terceirizadas para empresas privadas ou subidas para estruturas de governança transnacional. Assim, o recalibramento do nexo política/economia no capitalismo financeirizado não é, de modo algum, equivalente ao "desaparecimento do Estado". Ao contrário, os Estados continuam exercendo suas históricas funções repressivas e monopolizando os meios de violência - e o fazem, aliás, de formas cada vez mais novas e criativas.

28 Nesse caso, ademais, o poder público seria justificado como uma condição necessária para a coordenação do mercado onde o mercado for apropriado e como um necessário substituto dele onde ele não o for. Para uma explicação do papel específico dos mercados nas sociedades capitalistas, ver Fraser (2014a). Para algumas implicações relativas ao que os mercados podem/devem e não podem/não devem fazer, ver Fraser \& Jaeggi (2018). 
ser criticamente reelaborado como uma ordem social institucionalizada cujas atuais divisões entre economia, política, sociedade e natureza são inerentemente não democráticas, injustas e disfuncionais - e, portanto, têm precisão de transformação. Além disso, o ideal de justiça poderia ser desvinculado de sua encarnação centrada no mercado, truncada; ser reenquadrado para corresponder à verdadeira escala (transnacional) da interação social; e ser reimaginado de um modo encorpado e substantivo, como requerendo arranjos institucionais que permitam a todos participar como iguais na vida social. Por último, a visão fechada da história como admitindo somente um futuro (capitalista) poderia ser substituída por uma visão em aberto que permitisse a invenção de novas possibilidades - novas formas de capitalismo talvez, mas também novas sociedades pós-capitalistas. Sendo inteiramente possíveis ao menos em princípio, tais ressignificações poderiam servir como os núcleos de um novo senso comum contra-hegemônico propício à luta emancipatória.

Hoje, porém, ausente tal rearticulação, o senso comum prevalente predispõe seus sujeitos à quiescência, mesmo quando a contradição política do capitalismo assume uma expressão aguda e aberta. Nesse contexto, o "realismo" milita não só contra os esforços para obrigar os poderes estabelecidos à prestação de contas, mas também e especialmente contra os esforços para interpretar os "malogros" de tais poderes como expressão das contradições políticas sistêmicas do capitalismo financeirizado, contradições que podem e devem ser resolvidas pela transformação social. Em vez disso, parece bem mais sensato que as dinâmicas de crise que o indivíduo experiencia como fatalidades que não podem ser mudadas sejam interpretadas como dores crescentes que devem ser suportadas na rota para um futuro melhor, ou como pequenos solavancos na estrada para a emancipação através da capitalização empreendedora de si mesmo. Assim, faz-se com que a ação coletiva destinada a reestruturar o atual regime pareça sem sentido. ${ }^{29}$

Obviamente, a quiescência assume muitas formas e é periodicamente interrompida por explosões de raiva, algumas das quais parecem prenhes de possibilidade. Nos Estados Unidos, onde o senso comum neoliberal está disseminado, Occupy Wall Street conseguiu perfurar o véu ideológico e capturar a imaginação

29 Essa sensação da falta de sentido da ação coletiva também permeia os "núcleos protoideológicos" que Wolfgang Streeck recentemente decifrou nas "matérias-primas da vida cotidiana". Essas matérias-primas, do modo como ele as descreve, incluem a experiência de estar por conta própria, impossibilitado(a) de contar com a ajuda dos poderes estabelecidos; a sensação de que é necessário produzir, pelos próprios esforços, sob a aparência de "redes", as formas de integração social que antes eram fornecidas por instituições sociais e programas governamentais; e a experiência do orgulho, semelhante ao de um atleta, de poder (supondo que se pode) carregar tal fardo pesado sobre os próprios ombros. Para Streeck, essas experiências cotidianas podem ser, afinal, refinadas e transformadas em discurso público e tornar-se ideologia propriamente dita. Em todo caso, sua afinidade com o atual e muito entusiasmado senso comum neoliberal fornece um ponto de apoio a esse senso comum e é coerente com a valorização, feita por ele, do sujeito empreendedor, hiperindividualizado e despolitizado, descrito acima. Ver Streeck (2015). 
pública no começo da crise atual. Mas o movimento se demonstrou efêmero, dissipando-se tão rapidamente quanto irrompera, tendo legado pouco em termos de pensamento programático ou de estrutura organizacional. Hoje, por conseguinte, muitos que, nos Estados Unidos, sofrem do atual regime acreditam que seus anseios por uma vida melhor são melhor satisfeitos pelo "setor privado".

$\mathrm{Na}$ Europa, ao contrário, a aversão ao neoliberalismo é palpável. Mas suas principais expressões são o populismo autoritário e o antieuropeísmo xenofóbico, de um lado, e a passividade desesperançada e o neoanarquismo antiprogramático, de outro. É típico do último, bem como sintomático, um movimento francês denominado le Zadisme, o qual visa "defender" da predação empresarial "zonas" delimitadas, abandonando, no entanto, o objetivo mais ambicioso de transformar a ordem mais ampla que possibilita, na origem, tal predação. Certamente, o Podemos espanhol e o Syriza grego representam potenciais exceções; uma vitória de qualquer um deles seria transformadora. ${ }^{30}$

Alhures, a situação é diferente. Já há uma década ou mais, a América Latina tem contraposto à desdemocratização uma tendência democratizadora, oferecendo também a promessa tentadora de uma alternativa contra-hegemônica ao capitalismo financeirizado. Sua "maré rosa” de governos de esquerda e centro-esquerda surgiu de um vasto mar de lutas contra a neoliberalização, lutas que ativaram massas de moradores de favelas, povos indígenas e camponeses sem-terra, antes excluídos da vida política, juntamente com estratos da classe média e da classe trabalhadora. Indo diretamente contra a lógica global prevalente, a tendência latino-americana tem sido fortalecer o poder público - defendê-lo, ampliá-lo e transformá-lo. Embora contaminada, aqui e acolá, com o caudilhismo e o clientelismo, a Maré Rosa é o que o mundo tem testemunhado de mais próximo a uma contra-hegemonia. Todavia, suas chances de sucesso estão estreitamente atadas aos preços mundiais das commodities - e, portanto, são vulneráveis a uma queda duradoura da demanda chinesa. No capitalismo financeirizado, ao que parece, a "transformação numa só região" não é sustentável.

Noutra frente de batalha, ao mesmo tempo, movimentos sociais transnacionais têm desafiado frontalmente as instituições financeiras globais que estão canibalizando o poder público em todo o mundo. Iniciada em Chiapas e Seattle e propagada através do Fórum Social Mundial, essa estratégia da “alter-globalização" tem forjado conexões impressionantes entre correntes ativistas e movimentos sociais espalhados e remotos. Mas também ela é manietada por suspeitas anarchisant lançadas sobre a organização, o poder público e o pensamento programático de larga escala. ${ }^{31}$

30 Quando da redação deste texto (setembro de 2015), as chances de tal vitória parecem magras. Em longo prazo, o destino de ambos os partidos dependerá de sua capacidade de oferecer soluções contra-hegemônicas e transformadoras que mobilizem, ao invés de apaziguar.

31 Para uma crítica de tais suspeitas anarchisant, ver Fraser (2014c). 
Recusando-se a desenvolver uma visão institucional abrangente, ela tem malogrado, até agora, em convencer as populações subalternas desesperançadas de que "outro mundo [realmente] é possível”.

Por último, as várias correntes acima mencionadas têm falhado, até a presente data, em coalescer. Dispersas e “de oposição", mas não contra-hegemônicas, elas ainda têm de talhar um novo senso comum político que possa rivalizar com as depressivas platitudes do neoliberalismo. Apesar da realidade amplamente sentida de uma aguda crise sistêmica, o sofrimento intenso e o mal-estar alastrado não se convertem numa força prática para a transformação social. Nem a presente crise administrativa nem os déficits de legitimação que a acompanham dão origem a uma crise de legitimação no sentido habermasiano - muito menos a um duplo movimento polanyiano ou a um bloco contra-hegemônico gramsciano.

\section{Reflexões finais sobre a anatomia de um complexo de crise}

O complexo de crise do capitalismo financeirizado difere daquele do capitalismo estatalmente administrado em três aspectos. Primeiro, nos anos 1970, - locus central da crise era a política; naquele tempo, as disfunções econômicas do regime subsequente à Segunda Guerra Mundial estavam apenas começando a tornarse evidentes, e seus efeitos se mantinham relativamente circunscritos. Hoje, no entanto, a crise política anda de mãos dadas com uma crise econômica aberta e cuja severidade é visível para todos - e, além disso, com crises de ecologia e reprodução social evidentes. Assim, longe de suplantar essas outras contradições do capitalismo, a vertente política se entrelaça com elas e as exacerba. E, longe de ocupar uma única localização estável na sociedade capitalista, a crise de hoje muda rapidamente de lugar para lugar, estourando aqui e ali de acordo com o foco de incêndio du jour. ${ }^{32}$ Se a configuração precedente levou Habermas a falar de "deslocamento", a presente configuração nos tenta a falar, antes, de “metástase”.

Em segundo lugar, a crise do capitalismo estatalmente administrado foi uma crise na qual as perturbações sistêmicas impeliram uma massa crítica a retirar seu apoio do regime - pelo menos por algum tempo. Tendo montado um senso comum contra-hegemônico, os críticos do capitalismo estatalmente administrado puderam mobilizar uma gama impressionante (embora, em última análise, insuficiente) de forças para a transformação estrutural. Durante certo período, portanto, o cenário vislumbrado por Habermas parecia materializar-se: uma crise administrativa se tornava numa crise de legitimação. Hoje, no entanto, disfunções sistêmicas agudas, tanto políticas como econômicas, não são experienciadas pelo prisma de um senso comum contra-hegemônico. Dispersa e não programática, a oposição não consegue

32 Sobre essa qualidade que a presente crise tem de mudar de lugar, ver Thompson (2012). 
alçar-se ao nível de uma abrangente contestação da estrutura básica do capitalismo financeirizado enquanto uma ordem social institucionalizada. Pelo menos até a presente data, não houve qualquer passagem da crise administrativa a uma crise de legitimação.

O que explica essa segunda diferença entre esses dois complexos de crise? Por que a crise sistêmica do capitalismo financeirizado, malgrado multidimensional e severa, não provoca qualquer crise de legitimação? ${ }^{33}$ A chave reside - sugiro numa terceira diferença que diz respeito ao caráter qualitativo da crise política nos dois períodos em questão. No período do capitalismo estatalmente administrado, ao menos conforme sua interpretação por Habermas, o problema era arregimentar uma legitimação suficiente (e suficientemente apassivada) para o uso ampliado da capacidade estatal de assegurar as condições para a acumulação continuada e a apropriação privada do excedente social. O que estava em questão, noutras palavras, eram os fins (conformes com o sistema) para os quais o poder público era empregado e os meios (burocráticos) pelos quais ele era exercido. Não pairavam muitas dúvidas sobre seu escopo próprio nem sobre sua real capacidade. Hoje, porém, o problema é o poder público enquanto tal: sua legitimidade como um meio de coordenação, sua capacidade de controlar o poder privado, sua capacidade de resolver problemas sociais e a escala na qual ele pode ser empregado de modo efetivo e adequado à prestação de contas. No capitalismo financeirizado, pairam muitíssimas dúvidas sobre essas questões. Uma persistente campanha ideológica tem obtido bastante êxito em deslegitimar o poder público na imaginação pública, ao mesmo tempo que um coordenado assalto institucional o está esvaziando enquanto uma força prática. Hoje, portanto, a lógica sistêmica da economia capitalista perfura profundamente a substância do político, consumindo o poder público a partir de dentro. Desestabilizando suas próprias condições políticas de possibilidade, o atual regime não só ameaça destruir a si mesmo. Além disso, ele corre o risco de demolir a única força que poderia transformá-lo, despedaçando o principal veículo através do qual sua crise poderia ser resolvida de um modo emancipatório.

Essa terceira diferença introduz um dilema que, ainda que turvamente, é visível para muitos atualmente. Aqueles(as) que suportam as atuais aperturas do capitalismo financeirizado se defrontam com uma perplexidade: como as forças democráticas podem consertar um sistema disfuncional quando o próprio instrumento necessário à reparação está sendo pulverizado pelas dinâmicas desse mesmo sistema? Aqui proponho - reside a chave para a ausência de uma crise de legitimação atualmente. Aqui, no penetrante esvaziamento da política pela economia, reside o inflexível nó do

33 Num ensaio anterior, tratei dessa questão primariamente no nível da ação social. Aqui, no entanto, meu foco é a interação dialética entre ação social e dinâmicas sistêmicas. A respeito de minha incursão anterior, ver Fraser (2013). 
bloqueio histórico que Albena Azmanova chamou de "a crise da crise do capitalismo" (Azmanova, s. n.). Certamente, a erosão do poder público atua sobre a ação pública como um forte depressivo, ao passo que também ocasiona periódicas explosões antissistêmicas. Na medida em que essas explosões permanecem antiprogramáticas, anti-institucionais e antipolíticas, elas sintomatizam as contradições políticas do capitalismo financeirizado, mas não as confrontam de frente.

É certo que a contradição aqui dissecada não é a única inerente à sociedade capitalista. Nem é a desdemocratização o único fenômeno de crise que experienciamos hoje. No entanto, o objeto destas reflexões foi a vertente especificamente política de uma crise multifacetada e mais ampla, crise que também tem outras vertentes importantes - a econômica, a ecológica e a social -, as quais, tomadas conjuntamente, resultam numa crise geral. Trata-se, no fundo, de uma crise do capitalismo - ou, melhor, de uma crise de nossa forma historicamente específica e atual de capitalismo: a forma financeirizada, globalizadora, neoliberal.

A vertente política dessa crise, não obstante, é especialmente importante. Em termos práticos, ela é a chave para resolver as outras vertentes. Sem uma reinvenção do poder público, ${ }^{34}$ não há qualquer esperança de lidar exitosamente com as dimensões social, econômica e ecológica da crise. Portanto, a crise da democracia demanda nossa atenção tanto no que diz respeito à própria democracia como no que diz respeito a nossos outros problemas. Mas a desdemocratização deve ser considerada sob a luz correta. Longe de representar uma espécie independente de distúrbio político, ela expressa contradições sistêmicas profundamente arraigadas, embutidas na estrutura institucional do capitalismo financeirizado. 0 que se segue disso é claro: quem quer que venha a falar sobre democracia hoje deverá falar também sobre capitalismo.

\section{Referências}

Arendt, H. (1973). The origins of totalitarianism. New York: Harcourt, Brace, Jovanovich.

Arrighi, G. (1994). The long twentieth century: money, power and the origins of our time. London: Verso.

Azmanova, A. (s. n.). The crisis of the crisis of capitalism (manuscrito não publicado e depositado em arquivo da autora).

Bakhtin, M. (1986). Speech genres and other late essays. Edition by Caryl Emerson

34 Resta clarificar o que exatamente significaria reinventar o poder público hoje. Estipularei aqui, de todo modo, que isso não pode significar simplesmente reconstituir as capacidades do Estado territorial. Dada a escala de questões como o aquecimento global e a regulação financeira, dada a transnacionalização da produção e dadas as exigências inescapavelmente transnacionais da justiça, não há como retornar ao tipo de social-democracia nacionalmente enquadrada do qual gozaram os países ricos do centro sob o capitalismo estatalmente administrado. 
and Michael Holquist. Translation by Vern W. McGee. Austin: University of Texas Press.

Boltanski, L., \& Chiapello, E. (2006). The new spirit of capitalism. Translation by Gregory Elliot. London: Verso.

Brown, W. (2006). American nightmare: neoliberalism, neoconservatism, and dedemocratization. Political Theory, 34(6), pp.690-714.

. (2015). Undoing the demos: neoliberalism's stealth revolution. Brooklyn, NY: Zone.

Crouch, C. (2009). Privatised Keynesianism: an unacknowledged policy regime. British Journal of Politics and International Relations, 11, pp.382-399. . (2011). The strange non-death of neoliberalism. Cambridge: Polity.

Dardot, P., \& Laval, C. (2013). The new way of the world: on neoliberal society. Translation by Gregory Elliott. London: Verso.

Fraser, N. (2004). Hannah Arendt in the twenty-first century. Contemporary Political Theory, 3, pp.253-261. 36, pp.69-88.

(2005). Reframing justice in a globalizing world. New Left Review, . (2008). Abnormal justice. Critical Inquiry, 34(3), pp.393-422.

. (2009). Feminism, capitalism, and the cunning of history. New Left Review, 56, pp.97-117.

. (2011). Marketization, social protection, emancipation: toward a neoPolanyian conception of capitalist crisis. In: Calhoun, C.; Derlugian, G. (eds.). Business as usual: the roots of the global financial meltdown (pp.137-158). New York: New York University Press.

. (2013). A triple movement? Parsing the politics of crisis after Polanyi. New Left Review, 81, pp.119-132.

- (2014a). Behind Marx's hidden abode: for an expanded conception of capitalism. New Left Review, 86, pp.55-72.

. (2014b). Can society be commodities all the way down? Economy and Society, 43(4), pp.541-558.

. (2014c). Publicity, subjection, critique: a reply to my critics. In: Nash, K. (ed.). Transnationalizing the public sphere: Nancy Fraser debates her critics. Cambridge: Polity.

Fraser, N., \& Gordon, L. (2013). A genealogy of dependency: tracing a keyword of the US welfare state. In: Fraser, N. Fortunes of feminism: from state-managed capitalism to neoliberal crisis. London: Verso.

Fraser, N., \& Jaeggi, R. (2018). Conceptualizing capitalism. In: Capitalism: a conversation in critical theory. Medford: Polity.

Gill, S. (1998). New constitutionalism, democratisation and global political economy. 
Pacifica Review, 10(1), pp.23-38.

(2015). Market civilization, new constitutionalism and world order.

In: Gill, S., \& Cutler, A. C. (eds.). New constitutionalism and world order (pp.2944). Cambridge: Cambridge University Press.

Gramsci, A. (1971). Selections from the prison notebooks. Edition by Quintin Hoare and Geoffrey Nowell Smith. New York: International Publishers.

Habermas, J. (1975). Legitimation crisis. Translation by Thomas McCarthy. Boston: Beacon.

Harvey, D. (2014). The “new” imperialism: accumulation by dispossession. Socialist Register, 40, pp.63-87.

Lapavitsas, C. (2014). Profiting without producing: how finance exploits us all. London: Verso.

Polanyi, K. (2001). The great transformation. 2. ed. Boston: Beacon.

Rodgers, D. T. (2011). Age of fracture. Cambridge: Harvard University Press.

Sassen, S. (2000). Women's burden: counter-geographies of globalization and the feminization of survival. Journal of International Affairs, 53(2), pp.503-524.

- (2005). The global city: introducing a concept. Brown Journal of World Affairs, 11(2), pp.27-43.

Streeck, W. (2011). The crises of democratic capitalism. New Left Review, 71, pp.529.

. (2012). Citizens as customers: considerations on the new politics of consumption. New Left Review, 76, pp.27-47.

London: Verso.

. (2014). Buying time: the delayed crisis of democratic capitalism.

- (2015). Coping, doping, hoping, and shopping: prolegomena to a theory of capitalist legitimacy in the face of system disintegration. Palestra ministrada na conferência sobre "The legitimation crisis of capitalism", no Historisches Zentrum/Engels-Haus, Wuppertal, Alemanha.

Thompson, J. B. (2012). The metamorphosis of a crisis. In: Castells, M., Caraça, J.,

\& Cardoso, G. (eds.). Aftermath: the cultures of the economic crisis (pp.59-81).

Oxford: Oxford University Press.

Wallerstein, I. (1974). The modern world-system. New York: Academic Press.

Wood, E. M. (1981). The separation of the economic and the political in capitalism. New Left Review, 127(1), pp.66-95. 